\title{
LA ORDENACIÓN ECONÓMICA E INSTITUCIONAL DEL ESTADO DE AGUILAR EN LOS ALBORES DE LA EDAD MODERNA
}

\author{
JOSÉ LuIS DEL PINO GARCÍA \\ Universidad de Córdoba
}

\begin{abstract}
SUMARIO
Introducción.- 1. Las Ordenanzas de 1519.- 2. Los motivos de la promulgación.- 3. Los temas regulados: A. Establecimientos de la primera parte del Ordenamiento: a) Los concejos y cabildos. b) La administración de justicia. c) Otros oficiales del concejo. d) Abastecimiento y comercio. e) Aspectos sociales.- B. Establecimientos de la segunda parte: a) Leyes de defensa y fomento de los recursos naturales. b) Ordenanzas de protección a los sembrados. c) Disposiciones sobre los sembrados, dehesas y rastrojos. d) Leyes para los ruedos. e) Normas sobre las penas.
\end{abstract}

\section{INTRODUCCIÓN}

La promulgación de leyes de aplicación local en Andalucía ha pasado por diversas etapas desde el siglo XIII hasta el final del Antiguo Régimen. En un primer momento, el monarca solía otorgar un fuero, y a veces también una serie de privilegios, al núcleo urbano recién conquistado para atender a la organización e inmediata repoblación de su término, tierra o alfoz. Pero la insuficiencia o inadecuación de los fueros a las necesidades surgidas con el transcurso del tiempo dio lugar a que se promulgaran otros ordenamientos para dar solución a los diferentes problemas que iban surgiendo en cada localidad. La Corona, los municipios y los señores ejercieron en sus correspondientes áreas de influencia esa prerrogativa. Eran, según Ladero Quesada e Isabel Galán, poderes convergentes y no contrapuestos hacia un mismo objeto de reglamentación. Sin embargo, en caso de concurrencia prevalecía siempre la potestad de la Corona o la del señor sobre la del organismo municipal. Pero esto no solía suceder porque los reyes castellanos emitieron pocas ordenanzas después del siglo XIV y porque las normas 
municipales elaboradas por los concejos desde entonces solían ser presentadas para su examen y refrendo ante el Consejo Real'.

Del mismo modo, en las zonas de señorío, era frecuente que el titular del mismo hiciera suyos y promulgara de nuevo, si lo consideraba conveniente, ordenamientos ya vigentes editados por los municipios. Sin embargo, en esas áreas, la mayor proximidad de los agentes del poder aristocrático y el interés más inmediato y cotidiano del señor en el gobierno y administración de sus estados reducía mucho la posibilidad de autonomía municipal en todos los planos, aunque nunca la destruyera por completo. De hecho, la publicación de ordenanzas era una de las atribuciones más comunes de la potestad señorial ${ }^{2}$.

Así pues, las ordenanzas representan el estadio final, aunque permanentemente renovado, en la evolución de las formas de derecho local, en una época caracterizada, ya desde el siglo XIII, por la territorialización cada vez más amplia de las normas legales. Pero al margen de estas cuestiones, lo más interesante es acercarse a su contenido, que se refiere a los aspectos más variados de la vida y profundizar en el conocimiento de las comunidades locales, de sus manifestaciones vitales y de sus formas de organización.

Respecto a Córdoba, es de todos conocido que la ciudad recibió su fuero en 1241 del rey Fernando III, es decir, cinco años después de que fuera conquistada a los musulmanes. Ese fuero, del que se conservan dos textos, uno breve, escrito en romance y otro, más extenso y completo, redactado en latín, constituía en el momento de su promulgación la base de todo su ordenamiento jurídico. Pero, pronto comenzaría a ser completado tanto con privilegios y disposiciones reales como con ordenanzas elaboradas en el propio municipio. Dentro de la etapa inicial, la inmediata a la reconquista, se forma en Córdoba el concejo, cuya autoridad se extiende no sólo sobre la ciudad, sino también sobre el territorio -tierra o alfoz-de su jurisdicción ${ }^{3}$. La segunda etapa se desarrolla sin solución de continuidad a lo largo de los siglos bajomedievales y se prolonga hasta la caída del Antiguo Régimen. Durante esta última fase, el cuerpo legislativo de la ciudad se amplía y

1 M.A. Ladero Quesada - I. Galán Parra, Las ordenanzas locales en la Corona de Castilla como fuente histórica y tema de investigación (siglos XIII al XVIII), "Anales de la Universidad de Alicante», 1 (Alicante, 1982), pp. 221-222.

2 M.C. Quintanilua Raso, Nobleza y señoríos en el reino de Córdoba. La Casa de Aguilar (siglos XIV y XV), Córdoba, 1979, p. 242.

3 J.M. Escobar Camacho, La creación del Concejo de Córdoba a través de su Fuero, «BRAC», 104 (Córdoba, 1983), pp. 189 y ss.; también M.A. ORTI BeLmONTE, El fuero de Córdoba y las clases sociales en la ciudad de Córdoba y Nuevas notas al fuero de Córdoba, "BRAC", 70 (Córdoba, 1954), pp. 5-94, y 87 (Córdoba, 1965), pp. 5-25, respectivamente; J. Mellado Rodriguez, Los textos del Fuero de Córdoba y la regulación de los oficios municipales, Córdoba, 1990. 
completa considerablemente mediante la promulgación de diversas ordenanzas 4 .

Estas consideraciones de carácter general son perfectamente aplicables al caso concreto de las villas y lugares dependientes del señorío de Aguilar, cuyos vecinos estuvieron, en principio, sometidos al fuero de Córdoba, y luego, en los momentos de la señorialización, a las disposiciones y ordenamientos dictados por sus sucesivos señores. No creemos, sin embargo, que, a nivel puramente legislativo, esa ruptura con la legislación de Córdoba fuera tajante, entre otras razones porque muchos de los titulares de Aguilar ocuparon cargos relevantes en el gobierno de la ciudad. Además, en ciertos casos, las leyes de 1519 remiten a lo dispuesto por Córdoba.

\section{Las Ordenanzas de 1519}

Las ordenanzas aplicadas al núcleo campiñés del señorío de Aguilar, reunidas en forma de cuaderno, fueron promulgadas en 1519 por mandato de Lorenzo Suárez de Figueroa y Catalina Fernández de Córdoba, la legítima heredera del marquesado de Priego, la cual había sucedido a su padre, Pedro, por ser la mayor de las hermanas, en el año $1517^{5}$. Tales ordenanzas constituyen, sin duda, la más antigua codificación de ordenamientos señoriales encontrada hasta la fecha en el sur de Córdoba, porque de otros, que los hubo, sólo se conoce la noticia. En suma, tales leyes son de un enorme interés para la historia de ese amplio sector de la Campiña. Con este estudio pretendemos cubrir, siquiera sea de manera parcial, una parte del vacío historiográfico que pesa sobre la zona en tan singular aspecto.

El manuscrito se conserva en el Archivo Ducal de Medinaceli, en un cuaderno inserto en la Sección de Priego, bastante deteriorado, y cosido junto con una copia del siglo XVII. Ha debido de estar al alcance de muchos investigadores, pero nadie, que sepamos, se ha tomado el trabajo de estudiarlo ${ }^{6}$. La profesora Quintanilla, que conoce su paradero, apenas si pasó de la lectura de su articulado. De no ser así, resulta inexplicable que en su estudio sobre la casa de Aguilar escribiera «Las primeras [ordenanzas] fueron las destinadas a Aguilar, Montilla, Monturque, Montalbán, Puente

4 Muchos de esos ordenamientos y disposiciones se encuentran recopilados en los Libros de Ordenanzas de la Sección XIII, Serie X, del Archivo Municipal de Córdoba.

s Doña Catalina se casaría con don Lorenzo en 1518 en la villa de Aguilar. Sobre esta cuestión consúltese de Francisco Fernandez DE CORDOBA, ABAD DE RuTE, su Historia de la Casa de Córdoba, ed. Córdoba, 1954, pp. 173 y ss.

6 Archivo Ducal de Medinaceli, Sección de Priego, legajo 14, doc. núm 16, fols. 1-43 r. (En adelante ADM, Priego, 14-16, fol.) 
de Don Gonzalo y Santa Cruz, promulgadas el 20 de diciembre de 1519, y de las que sólo se conservan los epígrafes de cada apartado. Su contenido puede suplirse, en parte, con las de Cañete de las Torres, elaboradas en 1520 , con algunos añadidos posteriores, cuyo texto se conserva íntegro" ${ }^{7}$, siendo así que en su libro sólo se encuentran referencias a los enunciados de algunas leyes.

Esas ordenanzas, recopiladas en forma de cuaderno, son, pues, el principal y más antiguo texto legislativo que se ha conservado para el conjunto de pueblos que formaban parte del señorío de Aguilar. El momento de su promulgación coincide precisamente con uno de los períodos de mayor auge ordenancista que se produce en Córdoba en el tránsito de la Edad Media a la Moderna ${ }^{8}$. Hasta la fecha han permanecido inéditas, aunque el articulado de sus diferentes capítulos - no el contenido- era, según dijimos, ya conocido. Antes de iniciar su estudio, convendría plantear una serie de cuestiones.

¿Cómo se elaboraron estas ordenanzas? Según Quintanilla Raso, fue Lorenzo Suárez de Figueroa quien, al hacerse cargo de sus dominios, decidió efectuar una revisión de los ordenamientos existentes en todas sus villas, en la mayor parte de los casos olvidados, y, por tanto, incumplidos. Para ello envió como alcalde mayor al bachiller Juan de Figueroa, con objeto de que en cada una de ellas procediese a dictar las normas para que los usos y costumbres antiguos - a los que se añadirían algunas nuevas disposiciones- fuesen recopilados en un cuaderno de ordenanzas, que se expondría al conocimiento de todos sus vasallos. Pero al margen de ello, desconocemos el procedimiento empleado en la elaboración o recopilación de las mencionadas leyes. Es de suponer que ese individuo con la ayuda de los oficiales de cada uno de los municipios afectados elaborase ese informe, que luego se elevaría a la categoría de ley, para lo cual debió de ser necesaria la intervención profesional del bachiller o algún otro experto en la materia de legislar. Al menos así se hizo en la villa de Cañete donde los escribanos públicos copiaron todos los ordenamientos que se habían dictado hasta entonces y confeccionaron un cuaderno.

Ese trabajo no parece que fuese realizado prontamente, aunque en el articulado de las ordenanzas se hace referencia de manera continua a disposiciones anteriores, algunas de derecho consuetudinario, cuyo conocimiento debió de facilitar su posterior redacción. Tampoco podemos determinar la influencia que el conjunto de las normativas pudieran recibir de otras, aun-

7 M. C. Quintanilua Raso, Nobleza y señoríos en el reino de Córdoba, pp. 242-243.

${ }^{8}$ R. CORDOBA DE LA LLAVE, Poder municipal y control gremial. Legislación e impuestos en materia industrial del cabildo de Córdoba a fines del siglo XV, "Ifigea", V-VI (Córdoba, 19881989), pp. 176-177. 
que la presencia de algunas leyes cordobesas es clara. Es seguro, por lo demás, que esa labor legislativa no se hizo a espaldas de los legislados, porque unas veces parte de leyes y disposiciones anteriores y otras recoge costumbres antiguas de las localidades afectadas por la regulación, que son Aguilar, Montilla, Puente Genil, Monturque y Montalbán. Para ello resultó previo la elaboración de un informe: «...e por ser obra de gran utilidad e provecho con mucho cuidado mandamos ver lo que antiguamente fue hordenado y los usos y costumbres desta nuestra tierra y lo que más convenía al bien público y buena administraçión della e informados de todo ello por la obligaçión que tenemos a la dicha administraçión y buen regimiento destos nuestros pueblos y principalmente al serviçio de Dios nuestro Señor mandamos constituir y hordenar para las dichas villas y lugares y constituimos y hordenamos los estableçimientos, leyes y hordenanças siguientes»".

\section{LOS MOTIVOS DE LA PROMULGACIÓN}

El cuaderno de las ordenanzas consta de cuarenta y tres folios y su contenido aparece dividido, como es usual en otros establecimientos de la Baja Edad Media, en varios apartados: un prólogo donde se exponen los motivos que han llevado a su redacción; los títulos o capítulos de ordenanza, cada uno con sus correspondientes leyes y divididos en dos grandes apartados; la firma, en este caso de los señores de Aguilar; la fecha de la promulgación; y el testimonio de haber sido pregonadas.

Las razones de la promulgación de este libro de ordenanzas aparecen expuestas con claridad en el prólogo del texto legislativo y son suficientemente explícitas: "Mucho se deve trauajar en haçer leyes y hordenanças por las quales los pueblos sin larga ny dilaçión de pleitos sean mantenidos en justiçia y commo quiera que los señores antepasados desta Casa de Aguilar nuestros predeçesores de buena y memorable recordaçión hicieron estableçimientos para la administraçión dela cosa pública no ay dellos çierta recopilaçión y están dispersos en muchas partes y otros no vertidos debajo dela costumbre, lo qual no poca confusión a traido en las cabsas que se an tratado e pendientes y en otros ay neçesidad de aclaraçión y quede forma para el proçeso y execuçión delo que se estatuye y manda y en algunos casos conviene fazerse nueva provisión paresçionos cosa muy conveniente e nesçesaria mandar fazer un libro e volumen de hordenanças e estatutos que tenga lo que de aquí adelante se a de guardar en las dichas nuestras villas e lugares de Aguilar e de Montilla e la Puente Don Gonzalo e Monturque e Montalván...»10.

9 ADM, Priego, 14-16, fol. 1 r.4

10 Idem. 
Según se indica, pues, en el prefacio del cuaderno de ordenanzas, los señores de la casa de Aguilar, imbuidos del ideal cristiano de servir a Dios, se sintieron obligados a trabajar en la elaboración de leyes que fuesen de utilidad para el bien público, el gobierno y la administración de las villas y lugares referidos. Y lo hicieron recogiendo el espíritu de sus antecesores, quienes ya habían promulgado diversas normas. Sin embargo, existían otros motivos para acometer semejante empresa. Por una parte, no había ninguna recopilación de las normas jurídicas hasta entonces vigentes. Al contrario, los preceptos se encontraban dispersos y, por consiguiente, podía resultar complicado y difícil el desarrollo normal de la justicia. Por otra, cada localidad mantenía, según parece, en vigor la aplicación de sus respectivos privilegios, usos y costumbres, lo cual hacía más compleja la situación. Precisamente para evitar la anarquía que de todo ello se derivaba y aclarar más el panorama estatutario en aquellos pueblos del señorío, los marqueses de Priego decidieron afrontar la tarea de hacer por vez primera un libro de ordenanzas asumiendo parte de la legislación anterior -escrita o no- y completándola con nuevas leyes al objeto de presentar un código homogéneo y coherente.

\section{LOS TEMAS REGULADOS}

Los títulos en estas ordenanzas se distribuyen, según se dijo, en dos partes. La primera tiene diez capítulos, los cuales se refieren, fundamentalmente, a temas relacionados con la institución municipal, los oficios concejiles, las carnicerías, la protección del vino, el comercio y con los alardes y caballeros de cuantía, es decir, con cuestiones relativas a la gobernación y administración de los municipios y aspectos económicos de ámbito estrictamente local. Los establecimientos de la segunda parte, en cambio, centran más la atención en la defensa de los recursos naturales de los términos de las villas antedichas, con especial alusión a los ríos, montes y arbolado, heredades, dehesas y ganados, sembrados y rastrojos, fuegos, ruedos, colmenares y a las correspondientes multas o infracciones contra lo legislado. Es precisamente ese carácter punitivo el más sobresaliente de todo su articulado. Y es también la variada participación en el cobro de las penas lo que favorece el cumplimiento de tales ordenanzas.

En general, las leyes afectan a todas las poblaciones del estado de Aguilar; no obstante, ciertas normas parecen estar hechas solamente para los dos municipios más importantes: Aguilar y Montilla, los únicos que en ocasiones aparecen citados en los encabezamientos de los preceptos. No siempre es así, pues en muchas leyes se hace mención al resto de los núcleos rurales de ese señorío. En todo caso, parece siempre existir un orden en la 
denominación de los pueblos que responde, sin duda, a su diferente categoría: los dos primeros tienen el rango de villa; después se citan, en calidad de lugares, La Puente don Gonzalo -Puente Genil- Monturque y Montalbán, que, además, forman parte del término de Aguilar.

\section{A) Establecimientos de la primera parte del ordenamiento.}

Dentro de esa primera parte del cuaderno de ordenanzas, destacan, por el número e importancia de las disposiciones, los títulos primero y segundo referentes a los cabildos y a los oficiales del concejo.

\section{a) Los concejos y cabildos}

En este apartado, la normativa establece lo siguiente los miembros integrantes de los concejos de Aguilar y Montilla -alcaide, alcaldes, alguacil mayor, regidores, jurados, mayordomo y escribano- tenían que reunirse todos los lunes de cada semana a la hora acostumbrada en sus respectivas casas consistoriales, y no en otros lugares, para celebrar cabildo, cuyo contenido debía ser reflejado por el escribano del concejo de una y otra villa en el correspondiente libro de actas. Los capitulares estaban obligados a asistir a las sesiones del cabildo sin ser previamente convocados a ellas. De tener algún impedimento, tenían necesariamente que notificarlo, si no querían incurrir en pena, al alcalde y al escribano un día antes de la reunión.

En tales cabildos se trataban asuntos relacionados con la administración, el gobierno y la ejecución de las leyes. Además, la ordenanza contempla la posibilidad de convocar una sesión extraordinaria y abierta a todo el pueblo. En tal caso, en el cabildo se determinaba el lugar de la celebración. Los oficiales de Monturque, Puente Genil y Montalbán debían juntarse a cabildo el día que tuvieran por costumbre ${ }^{11}$.

11 "Porque estas nuestras villas de Aguilar e Montilla sean bien regidas y la cosa pública se administre commo deve, hordenamos y mandamos que se haga cabildo un día en la semana y que sea el lunes a la ora que se tiene de costumbre al qual bayan el alcaide e alcaldes e alguasil mayor y regidores e jurados e mayordomo de conçejo y el escriuano de conçejo y se haga en las casa de cabildo que en cada una delas dichas villas para ello son diputadas y no en otra parte y que el dicho cabildo se entienda en hordenar las cosas del regimiento sobre la guarda e execuçión delas hordenanças y buenos usos y costumbres y lo que pasare y se fisiere en el dicho cabildo se asyente y escriua por el escriuano de conçejo en el libro que para ello a de fazer y quando ocurrieren y subçedieren negoçios en que convenga llamarse el pueblo uniuerso se señale en cabildo el lugar donde el tal ayuntamiento se aya de fazer y que los dichos ofiçiales sean obligados el dicho día del lunes a yr a cabildo sin ser llamados solas 
Por otra parte, para evitar los fraudes y oclusiones que se hacían en las escrituras concernientes al concejo, se ordenó al escribano otorgar tales instrumentos públicos un día señalado en el cabildo o bien en otra sesión que contara con la asistencia de la mayoría de los oficiales ${ }^{2}$. Estaba prohibida la entrada en cabildo o ayuntamiento a las personas que no formaran parte del concejo, excepción hecha del alcalde mayor de los señores de Aguilar en el caso de que estuviese en la villa o lugar y quisiera asistir ${ }^{13}$. En cada una de las poblaciones debía, además, de haber un arca a buen recaudo donde se guardaba el correspondiente inventario de los bienes propios del concejo, así como todas las sentencias, mercedes y privilegios y las cuentas del mayordomo ${ }^{1.4}$.

Los mayordomos del campo, guardas y oficiales públicos del municipio debían denunciar, conforme a lo dispuesto en las ordenanzas, las penas que en aquella semana se habían hecho, para impedir que el concejo fuese defraudado; por ese motivo, si pasaban por alto esa obligación se les castigaba con multas e incluso, en casos de reincidencia, con la cárcel y la suspensión del oficio. Pero como esos oficiales podían estar cumpliendo otras funciones, se les permitía presentar la denuncia dos o tres días antes de la celebración del cabildo o en cualquier día de la semana siempre que lo hicieran ante el escribano del concejo o un alcalde.

El escribano, por su parte, estaba obligado a reflejar en un libro esas denunciaciones, las cuales, además, debía leer en cada cabildo. La acusación tenía que hacerse con juramento y fecha. El mayordomo del concejo debía de hacerse cargo de todas las penas que en la semana se hubieren impuesto para cobrarlas según el tenor de las ordenanzas y dar luego cuenta de ello.

penas contenydas en los capítulos de my el marqués conde çesando justo ympedimento y que este ympedimento se a de mostrar ante el alcalde y ante el escriuano de conçejo en un día dela semana antes de dicho cabildo y que de otra manera no dexe de yncurrir en la dicha pena el que no fuere y declaramos y mandamos que dela dicha pena contenyda en los dichos capítulos sea la mytad para el que lo denunçiare y la otra mytad para el conçejo y los ofiçiales que en el dicho cabildo se juntaren hagan el tal ayuntamiento y tenga tanto efecto commo si todos estubieran presentes y que en los otros lugares se faga el cabildo en el día que tuvieren señalado» (ADM, Priego, 14-16, fols. 1 v.-2 r.)

12 ADM, Priego, 14-16, fol. $2 \mathrm{r}$.

13 Ibidem, fols. 2 r.-2 v.

14 «Hordenamos y mandamos que el conçejo de cada una delas dichas villas e lugares tenga una arca que esté a buen recaudo en que esté ynventario en forma pública commo faga fee y prueva de todos los bienes así raíçes commo muebles e semovientes propios e rentas derechos y aç̧iones del conçejo y de todas las escripturas, sentençias, merçedes e priuilejios que touyeren y que demás del cargo que se fisiere al mayordomo de conçejo se lo faga cargo en cada un año delos dichos bienes por el dicho ynventario para que dé quenta e rasón de todo ello y en cada un año se bean las dichas escripturas porque sienpre se tenga memoria dellas y todo quede a buen recaudo" (ADM, Priego, 14-16, fol. 2 v.). 
Se ordenó también para evitar negligencias que el primer asunto a tratar en el cabildo fuese el relativo a las multas. Las guardas del ruedo estaban excusadas de hacer tales denuncias en el cabildo en el tiempo fijado en las penas que el concejo no tuviere parte, sino que debían denunciarlas solamente al dueño de la heredad ${ }^{15}$.

Durante el mes de enero de cada año, el concejo de las villas de Aguilar y de Montilla estaba obligado a visitar el término. Para ello, en el primer cabildo celebrado ese mes se debía diputar una comisión formada por tres personas, un alcalde, un regidor y un jurado. Con estos oficiales tenía que ir el escribano del concejo para dar fe de la visita e igualmente el mayordomo del concejo. En caso de encontrar alguna anomalía no debían de innovar ni restituir ni modificar nada de lo observado; sólo dar cuenta al concejo para que éste adoptase las medidas oportunas ${ }^{16}$.

\section{b) La administración de justicia.}

En los pueblos del señorío, los alcaldes o jueces ordinarios ejercían la adminstración de la justicia. Pero no eran los únicos. También los alcaides en grado de apelación y el alcalde mayor del estado gozaban de ese derecho. Por otra parte, determinados pleitos eran juzgados por el alcalde del alarifazgo. La ejecución de las sentencias era competencia del alguacil mayor. Pero, eran los titulares de la casa de Aguilar quienes tenían la última palabra en la resolución de los procesos judiciales para absolver o imponer más castigos a los infractores.

En cuanto a los cometidos desempeñados por los oficiales del concejo, sabemos por las ordenanzas que los alcaldes estaban obligados a ir con los

15 ADM, Priego, 14-16, fols. 2 v.-3 v.

16 «Hordenamos y mandamos que en cada un año durante el mes de henero el conçejo de cada una delas dichas villas e lugares sea obligado a visitar el térmyno e para ello en el primero cabildo de dicho mes de henero de cada un año diputen e señalen un alcalde e un regidor e un jurado y que con estos ofiçiales vaya el escriuano de conçejo que dé fee de la visitaçión y el mayordomo de conçejo y si alguna cosa fallaren mudada los dichos ofiçiales en daño e perjuisio del conçejo no ynoven ny fagan cosa alguna fasta lo dezir y denunçiar en cabildo para que allí se prouea lo que más convenga y se deua fazer y que el dicho conçejo de cada una delas dichas villas e lugares sea obligado a fazer la dicha visitaçión en el dicho tiempo por la forma que de suso es declarado so pena de cada dos mill marauedís, la mytad para nuestra cámara y la otra para quien lo denunçiare e que los dichos ofiçiales que fueren señalados para fazer la dicha visitaçión y los dichos escriuano y mayordomo de conçejo vayan a fazer la dicha visitaçión so pena de cada quinientos mrs a cada persona, el terçio para quien lo denunçiare y lo demás para el conçejo y que se faga la dicha visitaçión acostumbrada delos conçejos solamente por las villas de Aguilar e Montilla e no por los otros conçejos" (ADM, Priego, 14-16, fol. 3 v.) 
escribanos públicos que seguían las causas judiciales dos días a la semana a visitar a los presos a la cárcel, o al lugar donde éstos estuvieren encerrados, para agilizar la marcha de los pleitos. De esa visita tenía que quedar constancia en el auto correspondiente con la fecha -día, mes y año-, el lugar y los testigos. Además, el auto era firmado por el alguacil mayor u otra persona que supiese escribir y no fuese sospechosa ni estuviera emparentada con el escribano que entendiere en la causa ${ }^{-}$.

Era igualmente preceptivo que hubiese un libro de cárcel en todas las poblaciones del señorío para evitar pusibles fraudes y vejaciones en la admi-

17 "Los presos que están en la cárçel reçiben mucho daño quando en sus negoçios, pleitos e cabsas ay dilaçión y aquesta las más vezes viene por no ser bisitados por los alcaldes e juezes que de sus cabsas cono̧en, y porque la mayor provisión que se puede fazer es quitar la dilaçión e largura delos pleitos para que brevemente se dé a cada uno su justiçia, hordenamos e mandamos que los alcaldes o qualesquier juezes de las dichas villas e lugares ante quien se tratare algún pleito así ceuil commo criminal de qualquyer calidad que sea sobre que alguna persona o personas estén presos en la cárçel sean obligados a yr dos días en la semana a la cárçel o lugar donde estuvieren los dichos presos juntamente con el escriuano dela cabsa y el tal alcalde o juez dirá a los presos si quyeren dezir de su justiçia o alegar o pedir cosa alguna y hagan çerca delo que les fuere pedido lo que sea de justiçia y porque pueda constar commo el dicho alcalde o juez va los dichos dos días a la cárçel de cada semana se asiente así por abto en el proçeso e proçesos delos dichos presos en forma pública con día, mes y año, lugar e testigos so pena de docientos marauedís por cada día delos que dexaren de yr que son obligados, la mytad para los presos dela cárçel e la otra mytad para el alguasil mayor que lo denunçiare e sino para el que lo denunçiare e durante el ofiçio e cargo pueda el alcalde o juez ser convenydo e demandado, sentençiado y ejecutado por la dicha pena ante el alcalde mayor estando en la villa o lugar o doquiera que estuviere y fecha la denunçiaçión, luego el juez ante quien se fiziere faga traer ante sí el proçeso del preso e no fallando el dicho abto dé mandamiento de ejecuçión que luego se ejecute por la dicha pena y dentro de tres días que por esta hhordenança damos al tal juez o alcalde contra quien se proçediere por todo térmyno para dezir de su descargo sin que sea nesçesario otro fecho ny asignaçión ny mynisterio de juez se determyne lo que fuere justiçia condenándolo en la pena o declarándolo por condenado en ella no dando justo descargo y en otro día siguiente se faga trançe y remate dela prenda sin requerirse otra solemnydad, forma ny más çitaçión de manera que se faga verdadero pago dela dicha pena a las personas a quien aquella se aplicare declaramos que en segunda ynstançia pueda la parte agraviada ser oyda e defazerse el agravio si en la verdad le oviere seydo fecho. E otrosy mandamos que los escriuanos públicos por ante quien pasaren los dichos proçesos sean obligados a yr a la cárçel o lugar donde estuvieren los presos con los dichos alcaldes los dichos dos días en la semana sola dicha pena delos dichos dozientos marauedís que contra cada uno dellos se a de executar para las personas e por la forma que de suso va declarado y porque por ser el abto que a de yr en el proçeso en su propia cabsa del escriuano que le toca para se evadir e librar dela pena mandamos que el dicho abto de visitaçión de cárçel se firme e señale por el alguasil mayor o por algún testigo que sepa escriuir que no sea sospechoso ny pariente del tal escriuano y que de otra manera no prueue el abto y se proçeda a la execuçión dela dicha pena conforme a esta dicha hordenança” (ADM, Priego, 14-16, fols. 3 v. -4 r.). 
nistración de la justicia. En ese libro, el escribano debía hacer constar -y por ello recibía un maravedí- el nombre de la persona que apresó al supuesto malhechor, el motivo de la detención, el lugar donde ésta se realizó y el día de su ingreso en prisión. Llegado el momento, también anotaba la fecha en que alcanzaba la libertad, en qué grado y quien lo dispuso. Este mismo procedimiento se llevaba a cabo cuando el juez mandaba retener a las personas en sus propias casas o en otros lugares fuera de la cárcel. El libro se quedaba en poder del alguacil mayor, a cuyo cargo estaban también los presos. Por ese trabajo, dicho oficial podía cobrar al año doscientos maravedís en Aguilar y Montilla, cien en Puente Genil y dos reales, es decir, sesenta y ocho maravedís en las poblaciones de Monturque y Montalbán ${ }^{18}$. Evidentemente, los alcaldes también percibían una serie de emolumentos por las causas que juzgaban, pero esos salarios debian ajustarse al arancel que, dado por el titular del señorío, necesariamente tenía que estar colocado en las audiencias y lugares públicos "."

Para evitar fraudes y encubiertas en el cobro de las penas impuestas por los jueces, alcaides y alcalde mayor del estado en las causas sentenciadas, dado que el importe de las mismas era compartido por los señores y los concejos, era obligatorio que esos oficiales entregasen sus dictámenes, dentro de los quince días primeros a la resolución de los procesos, a los escribanos, los cuales tenían que depositarlos en un arca grande destinada a ese fin, que se encontraba ubicada en un lugar seguro y conocido de la casa consistorial y cuya cerradura se abría tan sólo con dos llaves, una la tenía el alcaide y la otra el escribano del concejo ${ }^{20}$.

18 ADM, Priego, 14-16, fols. 5 r.-6 r.

19) Ibidem, fol. $4 \mathrm{v}$.

21) "Después de sentençiadas las cabsas criminales conviene que conbste delos proçesos y sentençias para muchos efectos así para que no aya frabde ny encubierta en las penas pecuniarias de nuestra cámara e delas obras públicas e conste delo que los juezes hazen e aya pot todo claridad para el tiempo que convenga e las partes a quien pertenesçieren las dichas sentençias e proçesos los puedan allí fallar, mandamos que demás dela otra arca de que en el título ante deste se faze mençión aya otra arca grande en la casa de cabildo o en otro lugar çierto e seguro en la qual dicha arca esten todos los proçesoses e sentençias pasadas en cosa juzgada de qualesquier delitos e cabsas criminales que se ovieren tratado ante los dichos alcaldes $o$ ante el alcaide o nuestro alcalde mayor e que los dichos alcaldes e juezes dentro de quinze días primeros siguientes después que la sentençia fuere pasada en cosa juzgada sean obligados a mandar e fazer que los escriuanos por ante quien los dichos proçesos e sentençias ovieren pasado los lleven e pongan en la dicha arca suscritos y firmados en manera que fagan fee so pena de cada dozientos marauedís contra el alcalde o juez que en el dicho térmyno no fisiere leuar e poner el proçeso e sentençia que él oviere pronunçiado, la mytad para nuestra cámara e la mytad para quien lo denunçiare y que sola dicha pena y más de suspensión del ofiçio por un mes e más quanto fuere nuestra voluntad los escriuanos públicos por ante quien ovieren pasado los dichos proçesos y sentençias criminales lleven y pongan en la dicha 
Por otra parte, los alcaldes estaban obligados a residir en todo momento en sus respectivos núcleos de habitación, porque su ausencia generaba gastos y molestias a las partes implicadas en los procesos judiciales. Pero, como había en cada pueblo del señorío dos jueces ordinarios, las ordenanzas contemplan la posibilidad -al menos para Aguilar, Montilla y Puente Genil, los más populosos- de que tales oficiales se pudieran alternar en el ejercicio de sus funciones, siempre que garantizaran en ellos la administración de la justicia"l.

En estas ordenanzas también se hace referencia al procedimiento que debía de emplearse en los pleitos librados entre labradores y jornaleros por cuantías inferiores a los dos mil quinientos maravedís. Según se desprende de la lectura de su articulado, era frecuente que los dueños de las fincas retrasaran el pago de los salarios a los mozos que empleaban en las faenas agrícolas y que éstos, debido a la lentitud de los procesos judiciales, se avinieran a cobrar menos de lo previamente estipulado o incluso se marchasen sin percibir sueldo alguno. Para resolver esta situación, se ordena al denunciado abonar al denunciante la cantidad adeudada en el plazo de tres días, una vez interpuesta la demanda, independientemente de que el proceso judicial continúe y pueda ser incluso más tarde objeto de revisión ${ }^{22}$.

\section{c) Otros of iciales del concejo.}

En el cuaderno de ordenanzas se habla de los diputados del mes, pero no se dice quienes son tales oficiales. Sabemos por la documentación de Córdoba, que se trata de personas que han sido escogidas por los miembros del cabildo para desempeñar funciones muy diversas de control y vigilancia en el municipio. El oficio en Córdoba recae siempre en los capitulares. Allí solían, a fines de la Edad Media, ser tres los designados, dos caballeros y un jurado. Teóricamente, la elección debía de efectuarse el día primero de cada mes. Por ese motivo a estos oficiales se les conoce con el nombre de diputados del mes.

Como tales oficiales, tenían que cumplir una serie de obligaciones, las cuales aparecen detalladas en algunos de los capítulos del cuaderno de ordenanzas del señorío de Aguilar. Básicamente la responsabilidad que contraen al jurar el cargo es doble: procurar el abastecimiento de plazas y mercados y

arca los dichos proçesos y sentençias firmados de sus nombres y suscritos en manera que fagan fee dentro delos dichos quinze días porque los dichos quinze días se dan para que dentro en ellos puedan cobrar sus derechos e costas delas partes e la dicha arca tenga dos llaues la una tenga el alcaide y la otra el escriuano de conçejo" (ADM, Priego, 14-16, fols. 4 v. -5 r.).

21 ADM, Priego, 14-16, fols. 7 v. -8 r.

22 Ibidem, fols. 8 r. -9 r. 
controlar e inspeccionar las actividades artesanales y de otro tipo que en ellos se desarrollan para evitar el cohecho y el fraude.

Por ejemplo, los diputados tenían la obligación de ir a diario a las carnicerías y a la plaza del mercado para comprobar si todo discurría conforme a lo legislado y atender a su abastecimiento. También podían comprobar un día de los del mes y sin previo aviso si los pesos y medidas que allí o en otras tiendas y casas de venta se usaban se ajustaban al arancel del almotacenazgo, porque de no ser así, tenían facultad para imponer multas a los infractores, aunque no para obtener de ellos prendas ${ }^{2 i}$.

Al mismo tiempo, los diputados del mes fiscalizaban las funciones del almotacén. El oficio de almotacén era uno de los cargos concejiles de mayor tradición en los concejos andaluces ${ }^{24}$. Su cometido inicial consistió en la vigilancia del mercado y en la inspección de las pesas y medidas usadas en la localidad, al objeto de que se ajustasen en todo a los patrones y marcos oficiales. Igualmente tenía a su cargo todo lo referente a la limpieza de calles, plazas, carnicerías, pescaderías, muladares y demás lugares públicos. Con el paso del tiempo el cargo de almotacén se convirtió en una de las rentas de propios. Dado que existían multas y derechos inherentes a este oficio, resultó más comodo para los concejos arrendarlo al mejor postor que no designar a un funcionario encargado de hacerlos efectivos.

El almotacén era el depositario de los marcos oficiales. Además, estaba obligado a facilitar todo tipo de medidas a los que las solicitasen de acuerdo con lo establecido en el arancel del almotacenazgo. Pues bien, los diputados del mes, como oficiales natos del concejo, debían poner cuidado e informarse si el almotacén usaba correctamente su oficio, es decir, si tenía repeso contra el carnicero o el pescador el día de la carne o del pescado, si hacía limpiar las calles de la suciedad y cuidaba de que se vertiera el estiércol en los lugares destinados a ese fin o si había requerido alguna vez al año los pesos y medidas a los vecinos del pueblo. De no cumplir bien el cargo, el almotacén incurría en pena de uno, dos o tres reales, según la falta la cometiera por primera, segunda o tercera vez ${ }^{25}$.

Además, los diputados del mes debían de conocer durante el tiempo que ejercían el oficio las carencias existentes en el abastecimiento de la localidad e informar de todo ello al cabildo para que en él se pusiera remedio. En otro orden de cosas, estos oficiales percibían una tercera parte de las penas que imponían, aunque ellos también podían ser multados e incluso suspendidos por dos meses o más tiempo, según lo determinasen los titula-

${ }^{23}$ Ibidem, fols. 6 r. -6 v.

${ }^{24}$ Véase M. GonZÁlez Jiménez, Ordenanzas del concejo de Córdoba, "HID», 2 (Sevilla, 1975).

${ }^{25}$ ADM, Priego, 14-16, fols. 7 r. -7 v. 
res del señorio, si no usaban correctamente el cargo para el que habían sido elegidos. Pero para que conocieran bien sus funciones, el escribano del concejo, tres días después de haber sido designados los alcaldes, tenía que entregarles un traslado de esta ordenanza".

Otro de los cargos que aparece mencionado en el cuaderno de ordenanzas de 1519 referido al señorío de Aguilar es el de alarife. Por alarife se entiende albañil y cantero, oficios estos estrechamente relacionados con el mundo de la construcción. Como en el texto del ordenamiento referido se dispone que se habian de guardar las leyes del alarifazgo de Córdoba, "porque las dichas leyes son buenas e se escusan muchos en dichos debates y se ha poblado esta nuestra tierra"'" convendría hacer algún comentario sobre ellas a fin de comprender mejor la importancia de este oficio.

El alarife es un cargo de designación concejil. Según la ordenanza del alarifazgo de Córdoba, elaborada a instancias del concejo por Pedro López y promulgada el día 1 de febrero de $15\left(03^{28}\right.$, a la elección del cargo podían aspirar todos aquellos que reunieran una serie de requisitos, tales como, conocimient o y experiencia en el oficio, buena fama, honestidad, honradez, buen juicio y temor a Dios y a la justicia del concejo. Sin embargo, en Córdoba el nombramiento de los alarifes del concejo se hacía después de que los maestros de esa corporación gremial hubieran hecho de antemano una preselección entre los candidatos a ocupar el cargo. Una vez elegidos en el cabildo, debían prestar, como todos los oficiales del municipio, el juramento de que cumplirían bien las obligaciones del oficio.

Esas obligaciones eran muy variadas. En primer lugar, en su condición de oficiales del concejo, debían de realizar una serie de actividades para la ciudad. En las ordenanzas del estado de Aguilar, tales funciones sólo se insinúan: "lavores nuevas y viejas e caminos e veredas e servidumbres $e$ sobre las otras cosas tocantes al alarifadgo" "2". ¿Qué cosas? En el ordenamiento de Córdoba aparecen bien delimitadas. Básicamente, los alarifes estaban obligados a efectuar dos inspecciones anuales, una para conocer el estado de las murallas, torres, puentes, alcantarillas y pilares del núcleo urbano, y, otra, el día de Santa Lucía (13 de diciembre) para comprobar que la altura de los edificios se ajustaba a la legislación y dar cuenta de todo ello al concejo. Pero aparte de estas y otras actividades que pudieran ejercer

26) Ibídem, fol. $7 \mathrm{v}$.

27 Ibidem, fol. $9 \mathrm{v}$.

28 Se encuentran en el Archivo Municipal de Córdoba, en el Libro $1^{\circ}$ de Ordenanzas, Secc. XIII, Serie 10, fols. 131 r. a 168 v. y han sido estudiadas por J. PADILla GonZal.EZ, El alarifazgo de Córdoba (1478-1516), "Axerquía", 8 (Córdoba, 1983) y también en El alarifazgo de Córdoba (XV-XV'I), "Axerquía".

${ }^{29}$ ADM, Priego, 14-16, fol. 9 v. 
conforme a lo regulado en su ordenamiento, los alarifes estaban obligados a obedecer las órdenes del cabildo, que, en general, podían ser para realizar tareas de inspección o bien proyectos para adobar, conservar o construir alguna obra o edificio público. Una vez efectuado el trabajo, presentaban al municipio el correspondiente informe.

No acaban aquí las competencias de estos oficiales: En nombre del concejo cuidaban y mantenían en buen estado de conservación los espacios públicos, calles, caminos, plazas y ejidos; velaban por la buena calidad de los materiales principales de la construcción, adobes, tejas y ladrillos; vigilaban las labores de cualquier tipo realizadas en las casas particulares; igual atención debían de prestar a los caminos reales, alcantarillas, puentes, muros, etc; eran los medidores oficiales del concejo. En suma, los alarifes estaban facultados, dentro del ámbito de sus competencias, para denunciar a los alcaldes o al cabildo de la ciudad cuantas irregularidades observasen en toda clase de obras que se realizaran en la ciudad sin contar con la autorización previa del concejo.

Una de las más importantes funciones que los alarifes hacían era la de juzgar, con mandamiento de juez, todos cuantos litigios y debates surgieran por causa de edificaciones y de las servidumbres derivadas de las mismas: de vista, de paso, derecho al sol, al agua, etc. Otra de sus competencias era la de asesorar, mediante relaciones o informes, a los alcaldes del alarifazgo. Actuaban, asimismo, como ejecutores de las sentencias, especialmente cuando se trataba de derribar un edificio que se había construido al margen de la ley, una pared en peligro de caerse, un aljimez, unos poyos, unos soberados, etc.

En síntesis, esas tareas encomendadas a los alarifes de Córdoba en las leyes del alarifazgo, debieron igualmente, aunque en menor escala y a otro nivel, ser las mismas para los oficiales que trabajasen en las villas y lugares del señorío de Aguilar, pues fueron añadidas a las ordenanzas de 1519. No obstante, queremos advertir que, entre la fecha de promulgación del ordenamiento cordobés en 15() 3 y el último año referido, se elaboraron otros capítulos en 1515. En todo caso, esas leyes fueron consideradas provechosas por Lorenzo y Catalina, hasta el punto de afirmar que con ellas se habían poblado las tierras del estado. Sin embargo, las ordenanzas cordobesas debieron de ser adaptadas para su aplicación en el ámbito señorial. De hecho, en el tema de las penas se alteraron sustancialmente.

También, los señores de Aguilar dictaron normas sobre el procedimiento que había de seguirse en los pleitos y causas del alarifazgo a fin de no demorar el desarrollo de los procesos judiciales, que debían ser juzgados por el alcalde del alarifazgo, cuyo salario se equipara al de los alcaldes ordinarios en el arancel que para estos últimos mandaron publicar los marqueses de Priego con la particularidad de que si iba a resolverlos a la misma 
(asa donde se había originado el debate acompañado de los alarifes y testigo cobraba ocho maravedís a cada una de las partes enfrentadas, siempre que la vivienda se encontrara ubicada dentro de la villa o en sus arrabales. De lo contrario, se llevaría treinta maravedís por cada día que estuviere ocupado en la resolución del pleito. Pero, si no era así, es decir, si empleaba menos tiempo en solventar la causa, se le pagaba en función de las horas de trabajo empleadas más los derechos del proceso si existieren. Por su parte, el alcalde del alarifazgo debía obligar a las partes intervinientes en el litigio a pagar de su peculio un salario justo a los alarifes que él enviara a informarse del debate".

Otros capítulos del cuaderno de ordenanzas están dedicados a los escribanos públicos, que no hay que confundirlos con los escribanos del concejo. Ambos son notarios, es decir, personas con facultad de producir documentos dotados de autenticidad y capaces de garantizarlos de un modo eficaz para producir derechos y efectos procesales, en su caso. Ambos se convierten también en personas públicas, puesto que desempeñan una función ad publicam utilitatem pertinens, y entran a formar parte de una institución dotada en la Baja Edad Media de las facultades necesarias para dar esa credibilidad o fides pública". La diferencia, sin embargo, estriba en que los escribanos del concejo, además, ponían por escrito las decisiones del cabildo y daban fé, según vimos, de todas las escrituras o mandamientos surgidos de esa institución.

No tenemos muchas noticias sobre los escribanos públicos del estado de Aguilar. Ignoramos cuántos eran, pero su número debió de estar relacionado con la importancia de cada localidad. Tampoco podemos en este momento precisar si los elegía o simplemente confirmaba al frente del oficio el concejo o el titular del señorío. Por otros testimonios, sabemos que los escribanos debían de reunir, al menos en teoría, una serie de requisitos,

"Q "Que el alcalde del alarifadgo lleve los derechos en los pleitos que ante él se trataren segúnd que los alcaldes hordinarios los llevan conforme al aranzel y el que yo el marqués conde mande fazer delos abtos que ante ellos pasaren e si fuere a ver algún debate a la misma casa o lugar juntamente con los testigos e alarifes segúnd en la ley antes desta se dixo lleve dela yda ocho marauedís de cada parte quatro mrs siendo el debate dentro en la villa o en sus arrabales e si fuera fuera dela villa e de sus arrabales que lleve treynta marauedís por cada un día que se ocupare e si no estuviere día entero que se entiende desde ora de misa hasta ora de vísperas que lleve a este respecto por lo que estuviere e más los derechos del proçeso si los oviere e ansímysmo mandamos que el dicho alcalde haga pagar su justo e devido salario a los alarifes que mandare yr a ver el debate, lo qual se pague a costa delas partes» (ADM, Priego, 14-16, fol. $10 \mathrm{v}$.).

"Véase de L. Pascual Martínez, Estudios de Diplomática Castellana. El Documento Privado y Público en la Baja Edad Media: los esiribanos, "Miscelánea Medieval Murciana", VIII (Murcia, 1981), pp. 121 y ss. 
muchos de ellos, sin embargo, incumplidos, para ocupar el cargo: ser personas mayores de dieciocho años, honradas, de buena fama y económicamente suficientes, profesar la religión católica, no tener ninguna enfermedad o incapacidad física para ejercer la profesión, residir de manera permanente en los lugares de trabajo, y, sobre todo, saber bien escribir y tener una cierta formación jurídica y un conocimiento de las leyes vigentes para poder adecuar a ellas la voluntad de los particulares que solicitaban la documentación de los asuntos "?.

Una vez elegidos, los escribanos estaban obligados a prestar juramento, tras lo cual tomaban posesión de la escribanía. Sus competencias, por lo demás, eran muy amplias; en la esfera judicial se extendían a todo género de actos jurídicos, sin distinción entre asuntos civiles y mercantiles, y en la vida privada y social abarcaba casi la totalidad de los actos: venta, donaciones, capitulaciones matrimoniales, promesas de dote y arras, poderes, obligaciones, franzas, inventarios de bienes, información de limpieza de sangre, hidalguía o cautiverio, emancipaciones, testamentos, particiones y otros variados asuntos. También intervenían en la administración de la justicia manifestándose competentes en la documentación de los distintos actos procesales como eran las declaraciones de testigos, la redacción de sentencias, etc ${ }^{33}$.

Por otra parte, el sistema retributivo del oficio de escribano está basado en la percepción de emolumentos devengados del ejercicio de la función pública, cuyas cuantías, reflejadas en los aranceles, variaban según la naturaleza del trabajo realizado. El escribano, debía, obviamente, observar estrictamente lo prescrito por la ley, no pudiendo percibir más de lo establecido en ella, pero unas veces por la dilatada periodicidad de las revisiones arancelarias y su consiguiente desajuste $e$ inadecuación al coste de la vida, otras como consecuencia de la enajenación del oficio, y otras por confusión o desconocimiento, lo cierto es que estas prescripciones no siempre fueron cumplidas ${ }^{34}$.

En el cuaderno de ordenanzas de 1519 se denuncia el hecho de que los escribanos públicos del señorío de Aguilar atendían en ocasiones únicamente a sus ordenamientos e intereses y, queriendo cobrar más salario de lo estipulado a las partes que actuaban en los documentos, no hacían aquello a lo que estaban obligados: elaborar las escrituras que se les demandaba, escribir las quejas y denuncias y a dar fe de los autos, contratos u otros instrumentos solicitados. A esa situación se le quiso poner remedio obligando a esos escribanos a cumplir el contenido de lo dispuesto en el arancel que se hizo

i2 Ibidem, pp. 135-143.

33 Ibidem, p. 154.

Ibidem, pp. 156 y ss. 
por orden del marqués de Priego y a ejercer correctamente su oficio sin demora, a lo más dentro de los tres primeros días de que fueren requeridos, sin percibir más salario del que les correspondía por ley, pues de lo contrario incurrían en penas de $6(0)$ maravedís y suspensión del cargo por quince o más días, según fuera la decisión de los señores".

\section{d) Ahastecimient" y iomeriz"}

En las villas y lugares del señorío, el comercio, al igual que la industria, tenía un carácter marcadamente local. Prácticamente toda la actividad comercial debía de estar basada en el intercambio de productos de primera necesidad destinados a satisfacer la demanda interna de la población. De ahí que la venta de ciertos artículos elaborados por los vecinos tienda a realizarse en sus respectivas localidades y que los habitantes de ellas tengan preferencia en las compras sobre los forasteros.

Uno de los productos de mayor consumo debió de ser la carne, la cual fundamentalmente se vendía en las carnicerías, consideradas, al igual que las pescaderías, las plazas y los ejidos, por el derecho común, de propiedad concejil. En general se arrendaban anualmente en tiempo de Carnestolendas, de tal forma que quienes se hacían cargo de ellas - los carniceros- debían estar avalados por personas cuantiosas que se comprometieran a asegurar en todo tiempo el abastecimiento de carne. Esos menestrales, que tenían sus propias ordenanzas, estaban sometidos a la inspección y vigilancia del almotacén.

39 "Muchas vezes los escriuanos por llevar mayores derechos a las partes o por entender en sus hordenanças no fazen lo que son obligados e deniegan su ofiçio no queriendo dar las escripturas a las partes a quien pertenesçe e otras vezes no quieren asentar las quejas ny denunçiaçiones ny dar fee delos abtos, contratos y escripturas e otras cosas de que son requeridos e diçen que lo haran e no lo fazen ny quieren fazer y porque a esto no se a de dar lugar, hordenamos e mandamos que siendo requerido el escriuano público por alguna parte que le dé la escriptura que le pertenesçe aver aviendo pasado por el tal escriuano sea obligado a la buscar e darsela firmada e signada en manera que faga fee sin le llevar más delos derechos que por la dicha escriptura oviere de aver no le llevando ny pidiendo cosa alguna de guarda ny por el trauajo dela buscar segúnd que ya yo el marqués conde lo tengo mandado e quien lo faga e cumpla el tal escriuano alomás dentro de tres días después que fuere requerido so pena de seysçientos marauedís, la mytad para la parte e la otra para las obras públicas delas dichas villas e lugares e que sola dicha pena luego que fuere el tal escriuano requerido que haga o asyente algún abto o queja o contrato o escriptura lo faga e asyente sin se divertir ny apartar a otras cosas estrañas de su ofiçio, syno que luego acauando lo que tuviere presente haga e cumpla lo que le fuere requerido porque demás dela dicha pena yncurrirá en pena de suspensión del ofiçio por quinze días e más por quanto nuestra voluntad fuere" (ADM, Priego, 14-16, fol. 11 r.). 
Pero la carnicería no sólo era la tienda donde se vendía la carne, sino también, y esto es conveniente recordarlo, el lugar donde se sacrificaban las reses. Y de hecho, ambos aspectos se encuentran debidamente regulados en los capítulos de las ordenanzas a ellas referidos, que nos hablan de manera muy sucinta de los carniceros y obligados especificando tan sólo algunas de las muchas funciones que desempeñaban, entre ellas, las ya comentadas de procurar abastecer de carne sus establecimientos y de matar las reses de los labradores y vecinos de las villas y lugares donde trabajan.

Así, en cada pueblo del señorío, según la fecha que tuvieran sus vecinos por costumbre, los oficiales del concejo procedían a pregonar la subasta de las tablas de las carnicerías por toda la comarca a fin de que estuviesen rematadas a mediados de la Cuaresma en favor de aquéllos que hubieran ofrecido los precios más baratos de venta al público. Haciéndose así, los carniceros beneficiados en la subasta tenían todavía tiempo -media Cuaresma- para proveerse de carne cuyo consumo, sin embargo, estaba canónicamente prohibido durante todos los días de la Cuaresma, es decir desde el miércoles de ceniza hasta el día de Pascua de Resurreción, exceptuándose los domingos y a los enfermos con licencia. De esa manera se quería evitar la especulación que se venía produciendo en los precios de las carnes que solían dispararse al alza como consecuencia de que, antes de la promulgación del cuaderno de ordenanzas, el pregón se hacía al principio de la Cuaresma y el remate al final de ella ${ }^{36}$.

No conocemos el contenido de las ordenanzas referidas a las carnicerías para los pueblos del señorío, aunque en aquel cuaderno se dice expresamente que eran buenas $y$, por tanto, merecedoras de ser cumplidas y conservadas. En ese sentido, lo único que ahora, en 1519 , se hace es mejorar e incrementar la cuantía de las penas de algunos aspectos: Por ejemplo, por no dar abasto se impone una multa de sesenta maravedís, y por darlo malo doscientos. No debía, por consiguiente, admitirse ni pesarse la carne que estuviera en mal estado, tampoco la de res que hubiese sido sacrificada fuera de la carnicería, ni la que no fuese apta para el consumo humano. De hecho, el antiguo ordenamiento establecía una pena de sesenta maravedís para aquellos que portaran reses muertas a las carnicerías, tasa que ahora se eleva a quinientos maravedís ${ }^{37}$.

En otro orden de cosas, antiguamente los vecinos de las localidades tenían regulada la costumbre de llevar los martes de cada semana a pesar y a matar sus animales a la carnicería, pagando treinta maravedís por tajón, es decir, por los cortadores y las herramientas que éstos empleaban. Esa cuantía aumenta el doble a partir de la promulgación del cuaderno de orde-

36 ADM, Priego, 14-16, fol. $11 \mathrm{v}$.

${ }^{7}$ Ibidem, fols. 11 v.-12 r. 
nanzas. Pero el obligado o cortador que realizaba el despiece del animal quedaba igualmente comprometido con el dueño de la res a pesarle toda la carne de carnero que le llevara ese día hasta acabar el trabajo, aunque para ello le fuera necesario emplear el día siguiente. Asimismo, no se tiene en cuenta el capítulo de las ordenanzas de Córdoba respecto al precio de las carnes, pero si el obligado no tuviere limpia la carnicería tenía que pagar veinte maravedís al almotacén del pueblo y quinientos si no daba abasto. Además, tenía que comprar el ganado a su costa ${ }^{i x}$.

Por otra parte, el diputado del concejo estaba obligado a llevar un libro para escribir el número y calidad de las reses vacunas objeto de peso y así evitar los daños y hurtos que solían producirse en el sacrificio de los animales. Los carniceros tenían prohibido dar muerte al ganado de noche en las carnicerias, mataderos y casas. Esa labor la tenían que realizar públicamente de día, con el fin de que se conocieran los hierros, marcas y señales de las reses. Todo ese trabajo era, además, registrado por los diputados o personas públicas que tuvieran a su cargo la misión de requerir e inspeccionar las carnicerías en el libro correspondiente, especificando la cantidad de animales sacrificados al día, la fecha de la matanza y el color, hierro y señal de cada una las reses. El carnicero tenía también que preservar un día completo el cuero del animal, sin quitarle las orejas ni privarle de otras señales por donde comúnmente el ganado vacuno se solía identificar. Los zapateros, curtidores y vecinos que lo comprasen debían mantener durante diez días tales marcas y señales de la piel.

Las ordenanzas contemplan también una posibilidad: Si el carnicero, el obligado o el cortador hacían la matanza de noche y en aquella misma semana desaparecía algún animal quedaban obligados a pagar una multa por robo en caso de que, desconocida la identidad del ladrón, no pudiera demostrar su inocencia y la res fuera reclamada por algún vecino o forastero. Esto si cometían la infracción por primera vez. Si reincidían en el delito la cuantía de la pena se doblaba e incluso se les castigaba físicamente. Todo esto se escribía también en aquel libro, que, por otra parte, debía ser entregado cada fin de mes al nuevo diputado ${ }^{34}$.

Otros productos de consumo y venta fueron igualmente regulados en el cuaderno de ordenanzas de 1519. En este sentido, se dispuso, recogiendo una práctica antigua, que los vecinos de Aguilar, Montilla, La Puente Don Gonzalo, Monturque y Montalbán pudieran en sus respectivos núcleos y términos sacar por el tanto cualesquier artículos que se vendieran en ellos: el plazo fijado para que tuviese lugar la saca era de nueve días a partir de la venta realizada para los bienes muebles y de tres meses para los raíces. Esta ley

is Ibidem, fols. 12 r. -12 v.

is Ibidem, fols. 12 v. $-13 \mathrm{r}$. 
del tanto por tanto, sin embargo, no podía ser utilizada en las compraventas realizadas entre los vecinos de las poblaciones del señorío, excepto entre los obligados, sino que únicamente se aplicaba a la venta de productos hecha por gentes de otros lugares. Tampoco se usaba en la comercialización de semillas, pues resultaba más provechoso que éstas salieran fuera del estado. Y, en cuanto al aceite que se vendía en los molinos, se ordenó que el molinero o arrendador de la aceña pudiera tomarlo para sí por el tanto ${ }^{* 11}$.

Por el contrario, se prohibió, como era costumbre, sacar lana del señorío o venderla por ese sistema a los forasteros bajo multa de dos mil maravedís. El infractor de la norma se exponía a perder la lana o a pagar el valor de su estimación si se sospechaba que iba a venderla fuera o lo tomaban en camino en tiempo que no solía llevarse al lavadero, aunque, los señores se reservaban la facultad de conceder licencias a los vecinos que quisieran llevar la mitad de su lana a otra parte de sus dominios. La otra mitad, en cambio, debía ser vendida en el pueblo al precio conveniente y que se pudiera concertar. Los lugares del señorío, es decir, La Puente don Gonzalo, Monturque y Montalbán tenían, en cuanto a precios se refiere, que seguir lo establecido en las villas de Aguilar y Montilla ${ }^{41}$.

Era también costumbre muy usada entre los vecinos del señorío de Aguilar sacar por el tanto a la res vacuna que el obligado tuviera atada al palo del matadero, siempre que el campesino que la adquiriese así asegura-

11) ADM, Priego, 14-16, fols. 13 r.-14 r.

41 "Porque es hordenança muy antigua aprouada por los señores desta casa nuestros anteçesores e usada por los vezinos delas dichas villas e lugares e fallamos ser en mucha utilidad y provecho de nuestros vasallos que no se pueda sacar lana delas dichas villas e lugares, hordenamos e mandamos que de aquí adelante se guarde la dicha costumbre y que no se pueda sacar lana a vender a fuera parte so pena dela perder o su estimaçión al que la sacare e llevare para vender y que se presuma que la lleva para vender fuera o que va vendida para fuera si la toman en camyno en tiempo que no va al lavadero ny se suele lavar la lana e commo dicho es aviéndola levado fuera a de pagar su estimaçión quedando en nos reservado quando por fazer merçed a alguna persona le dieremos facultad e liçençia para la poder sacar fuera o vender a quien quisiere en lo qual ternemos mucha moderaçión por el bien e pro delos pueblos e porque los señores delos ganados sean en algo aprouechados les damos facultad que puedan levar sin liçençia ny facultad alguna la mytad dela lana que tuvieren afuera parte o donde quisieren y que la otra mytad quede en el pueblo y la ayan los vezinos por el presçio que en la villa valiere e mejor se pudiere conçertar e para los dichos lugares dela Puente, Monturque e Montalván que se mire al presçio commo valieren en Aguilar y Montilla y porque nuestra villa de Santa Cruz se aprovecha del uso común de leña dela nuestra villa de Montilla, declaramos e mandamos que por los efectos dela ley suso dicha del tanto por tanto los vesinos de Santa Cruz se ayan por vesinos de Montilla e los de Montilla por de Santa Cruz para en los otros efectos no aclarando ny mudando cosa alguna syno que cada pueblo se quede en sus usos e costumbres e derechos e preuyllejos e facultades" (ADM, Priego, 14-16, fol. 14 r.). 
se que el animal iba a ser utilizado en las faenas agricolas. Esa práctica tendía evidentemente a favorecer la labor en los campos. Por ese motivose reconoce y se eleva, en las ordenanzas de 151\%, al rango de ley. Para hacerse con la res el labrador sólo tenía que demostrar con su juramento ante el juez que la bestia iba o estaba atada para ser sacrificada en el matadero. A veces, ocurria, no obstante, que el obligado para evitarlo lisiaba al animal o bien le daba prontamente la muerte, lo cual era considerado delito y, como tal, fuertemente sancionado con multa de mil maravedís y tres días de cárcet $\mathrm{H}^{\mathrm{H} 2}$.

Estas ordenanzas, pues, tienden a favorecer, la agricultura y la comercialización de los productos internos frente al exterior adoptando medidas proteccionistas. Esto es asimismo evidente en la regulación que se hace sobre el vino. En este sentido, los marqueses de Priego, prohibieron expresamente la venta de vino foráneo, sobre todo en Montilla, cuya producción debía de ser ya importante por esas fechas, pero también en otras localidades, como Aguilar, La Puente don Gonzalo y Monturque. En suma, ningún vecino podía traer vino de fuera a esos pueblos a no ser que lo hiciera para su autoconsumo y antes del día de San Juan (24 de junio). No obstante, en determinados momentos, el concejo de esas poblaciones, reunido en cabildo, podía, previo informe de los señores del vino, autorizar la entrada de vino procedente de otra parte para el abastecimiento general del pueblo, siempre que hubiese necesidad o carestía. De lo contrario, las autoridades municipales mandaban pregonar que no se pudiera meter tan preciado líquido en el pueblo hasta tanto no se consumiera el de los vecinos o la provisión del pueblo conviniese. La infracción a esta ley se castigaba con multa de seiscientos maravedís y pérdida de las bestias y aperos ${ }^{43}$.

En Aguilar también se guardaba la ley del vedamiento. Los titulares del señorío determinaron que no hubiera, en cambio, día limitado para la entrada del vino, "sino que quando oviere nesçesidad e no baste el vino del pueblo se prouea por el cabildo y esta mysma declaraçión se guarde en los dichos lugares de La Puente Don Gonzalo e Monturque»" Esa protección les lleva a los señores a ordenar también que ningún regatón o vecino pudiera comprar ese producto para revenderlo después en su casa. No obstante, podía solicitar al cabildo la licencia para venderlo en otra parte y obtener el correspondiente permiso, con tal de que no lo diese a mesonero, tabernero o a "persona cosaria" y declarase el lugar donde pensaba comercializarlo ${ }^{45}$.

El título octavo de la primera parte de las ordenanzas está dedicado por

42 Ibidem, fol. $14 \mathrm{v}$.

4h Ibidem, fol. $15 \mathrm{r}$.

in Ibidem, fol. $15 \mathrm{v}$.

is Idem. 
entero a regular la actividad de los regatones o intermediarios que compraban las mercancías para luego revenderlas a mayores precios. Una vez más, se pone de manifiesto el interés de los señores de Aguilar en demostrar que "la utilidad pública e de muchos se a de preferir a la privada e de pocos»". Por ese motivo, ordenaron, de acuerdo con el uso y establecimientos antiguos de las villas y lugares de la Campiña, que los regatones o tenderos no pudieran adquirir el producto hasta pasados tres días de haber sido expuesto públicamente en la plaza. Podía ocurrir, no obstante, que el comerciante venido de fuera decidiera marcharse a otra parte llevándose consigo los artículos que no hubiera vendido. En este caso, los señores autorizaban a los regatones a comprar la prenda para evitar mayores perjuicios al pueblo. Era, sin embargo, preceptivo que el vendedor y el regatón fuesen al alcaide y ante el escribano del concejo, o en su defecto en presencia de cualquier otro escribano público de la localidad, el comerciante jurase que nadie le había ofrecido dar por la mercancia tanto dinero como el regatón. Todavía, el vecino, dentro del plazo de los tres días en los que el forastero estaba obligado a permanecer en el pueblo, podía tomar la parte que quisiera de la mercancía por el tanto ${ }^{47}$.

\section{e) Aspectos sociales}

Lamentablemente, en estas ordenanzas no se hace mención a cuestiones relacionadas con la demografía ni tampoco con la estructura social imperante en los pueblos campiñeses de esa época. En general sólo hablan de vecinos y moradores, pero nunca de categorías sociales, las cuales únicamente pueden vislumbrarse en ese texto, y no de manera completa, a través de las diversas actividades profesionales que en él aparecen. Entre ellas, destacan los cargos desempeñados por los oficiales del concejo, figurando entre ellos y en primer lugar el alcaide, a quien siguen en orden de importancia los alcaldes, regidores, alguacil mayor, mayordomo, escribano y otros funcionarios -guardas y alarifes por ejemplo-, cuyo número es difícil de conocer. Por encima de todos ellos se encuentra la figura del alialde mayor y en última instancia los señores del estado. La diferencia social y económica entre éstos últimos y el conjunto de los vasallos del señorío, la mayoría de ellos campesinos, era sin ningún género de dudas abismal. Pero entre esos vasallos, existían del mismo modo distintos niveles de renta. Se habla así en las ordenanzas de amos, propietarios de cortijos, aparceros, jornaleros, mozos o criados. También se distingue al ganadero del pastor. Entre los integrantes

46 ADM, Priego, 14-16, fol. 16 r.

47 Ibídem, fols. 16 r.-16 v. 
del grupo de privilegiados, las actividades agropecuarias debieron de ocupar un lugar relevante.

Sorprende, por otra parte, que en las ordenanzas no se incluyan las tareas industriales y artesanales del señorío. Apenas si se citan determinados artesanos, como zapateros y curtidores. Sin embargo, es evidente que existió una mayor diversidad de oficios y de industrias en los pueblos del señorío, aunque es imposible cuantificar y apreciar su número e importancia. Tampoco debía de existir un elevado volumen de producción artesanal, al menos en la casi totalidad de los sectores industriales, porque no se han encontrado todavía indicios de que se realizaran exportaciones de artículos de esa naturaleza. Todo apunta, pues, a una producción de carácter local, orientada a satisfacer las demandas y las necesidades internas y más primarias de cada población. De hecho, está probado por otros testimonios la existencia de instalaciones relacionadas con la industria agroalimentaria -molinos de trigo y almazaras, salinas, lagares y hornos de pan- y la transformación de materias primas tales como el barro -tejares, alfares-, las pieles y los cueros -tenerías, batanes y curtidurías- y elaboración de los productos textiles -tintes-. En cualquier caso, en el texto de las ordenanzas sólo se mencionan dentro del sector terciario a los carniceros, zapateros, curtidores, mesoneros, taberneros y regatones.

Quienes sí aparecen nombrados de manera genérica son los caballeros de cuantía, también llamados de premia, es decir aquéllos cuyo nivel de rentas -un mínimo exigido en las leyes del reino- les permitía mantener un caballo y armas para la guerra. Son ellos los únicos obligados a pasar periódicamente revisión en los alardes, los cuales se hacen una vez al año en el mes de junio durante la festividad de San Pedro. Llegada esa fecha, todos tenían que presentarse después de celebrada la misa con su equipo -montura y armas- ante el alcaide y el escribano del concejo debía de dar testimonio del acto, que nada tenía de protocolario, pues quien acudiese sin caballo incurría en la pena de mil maravedís y se le comminaba a encontrar otra cabalgadura en el plazo de dos meses ${ }^{48}$. Desde luego, este tipo de función,

\footnotetext{
48. "Mandamos que las premáticas destos reynos que hablan çerca delos caualleros de contía, e dela contía que an de tener y delos que nuevamente se an de hazer contiosos y delas armas que han de tener se guarden y cumplan y executen solas penas dellas y mandamos y hordenamos que los vezinos e moradores delas dichas villas e lugares que tuvieren la contía dela ley hagan en cada un año alarde el día del señor san Pedro del mes de junio después de misa dicha con sus armas e cauallos ante el alcaide dela tal villa o lugar el qual dicho alcaide tenga cargo de ver las personas que deven tener de premia los dichos caualleros y delos apremiar a ello solas penas que les pusieren, las quales nos le avemos por ynpuestas y que aquellas se executen en sus personas y bienes y que el tal alcaide tenga cargo de requerir e resçebir el dicho alarde y lo resçiba públicamente ante el escriuano del conçejo dela tal villa o lugar y al que en el dicho alarde no hallare con cauallo yncurra en pena de mill marauedís
} 
tan necesaria en la Frontera, debía de resultar bastante gravosa para quienes obligatoriamente la ejercían, a pesar de los privilegios de que disfrutaban. De hecho, el alcaide, que actuaba en cada pueblo como caudillo militar, tenía la obligación de corregir cualquier anomalía en la prestación del servicio y también la de averiguar anualmente qué personas disponían del dinero estipulado para ser caballeros de cuantía y nombrarlas como tales.

Una vez realizados los alardes, los señores de Aguilar -o la persona que dejaran al frente del estado en su ausencia- debían ser debidamente informados. Para ello se les enviaba una copia notarial autentificada del alarde dentro de los quince días primeros siguientes a la celebración de la revista militar. La pena por incumplir esta norma era de cinco mil maravedís, una suma respetable si se compara con otras que aparecen en estas ordenanzas ${ }^{40}$. También era grande la multa impuesta a quienes vendiesen caballos sin licencia, con el agravante de que si el infractor era caballero de cuantía tenía que ingresar en prisión hasta tanto compraba otro animal "tan bueno commo el que vendió o el tal alcaide tenga entera satisfaçión»"

Por útimo, esta primera parte de las ordenanzas concluye con una ley referente a la compraventa del ganado caballar. Se considera mayor caballos, potros, yeguas y mulos, y, menor, las bestias asnales. En esos tratos se respetan antiguas costumbres. Así, el comprador podía en los nueve primeros días de la adquisición devolver al vendedor el animal si notaba alguna falta en él, pero debía abonar un real por la bestia menor y dos reales si fuera mayor por cada día que la hubiera tenido en su poder, cuantía que se dobla si sacaba la bestia fuera del término, además del dinero que tenía que pagar en caso de que le entregara el animal con el daño recrecido o alguna tacha nueva. De esa manera se defendía, por un lado, el derecho del comprador, que contaba con un plazo razonable para darse cuenta de cualquier tipo de defectos que tuviere el animal, y, por otro, el del vendedor, puesto que a veces compraban animales para realizar viajes y luego los devolvían alegando que tenían alguna deformidad y ésto era únicamente valido para los tra-

para nuestra cámara y que dentro de dos meses sea obligado comprar e thener comprado cauallo de buena manera y no lo comprando que de sus bienes el tal alcaide lo compre e se lo faga tener apremyándole a ello por todo rigor de derecho e otrosy que los dichos alcaides en cada un año se ynformen delas personas que se pudieren hazer de contía e hallándoles tener la contía dela ley los apremye e declare por caualleros de contía para todo lo que fueren obligados e confirmamos a los dichos caualleros de contía los preuyllejos, graçias e franquezas que por ser caualleros de contía tienen e mandamos que les sean guardados tan cumplidamente e segúnd que hasta aquí les han valido y les han sydo guardados" (ADM, Priego, 1416 , fols. 16 v. -17 r.).

49 ADM, Priego, 14-16, fol. $17 \mathrm{r}$.

so) Ibídem, fol. $17 \mathrm{v}$. 
tos que se realizaban entre vecinos de un mismo pueblo. En los otros casos debía de guardarse el derecho común ${ }^{\text {i: }}$.

\section{B) Establecimientos de la segunda parte}

Según decíamos, los establecimientos de la segunda parte están por entero dedicados a leyes para preservar los términos de las villas y lugares del señorío. En total son once títulos y cincuenta y una disposiciones, que nos ponen de manifiesto algunas de las actividades económicas más significativas del estado de Aguilar. En ese sentido, la economía de los pueblos campiñeses pertenecientes a ese señorío estaba basada en la agricultura y en la ganadería, según se deduce de la lectura de estas ordenanzas. Relativamente alejados del gran centro urbano de Córdoba, la industria manufacturera y el comercio con el exterior no parece que tuvieran demasiada repercusión de cara a la producción ni al consumo, más que el necesario para el autoabastecimient () o, a lo más, para las relaciones comerciales con otras localidades vecinas. Junto a esas actividades del sector primario, la caza y la pesca, realizada ésta fundamentalmente en los ríos Genil y Monturque, constituían otras fuentes de riqueza, aunque de menor importancia que las anteriores.

Es de destacar como una nota importante la preocupación de los señores del estado por preservar los recursos naturales existentes y potenciar el desarrollo de las actividades agropecuarias. Todo lo cual es objeto de una depurada legislación para su mejor provecho, protección y fomento. En agricultura los principales cultivos eran, como venía siendo habitual desde la Antigüedad, los cereales, entre cuyas especies, denominadas genéricamente con el nombre de "panes", se citan el trigo, la cebada, la escaña, el jarvanzo y el centeno. Sobresale el cultivo del viñedo, sobre todo en el término de Montilla y hay continuas alusiones al olivar. Se habla asimismo en estas ordenanzas de habares y de garbanzales; la producción hortícola, condicionada a los cauces de los ríos, era a base de frutales, leguminosas - no se menciona ningún producto- y linares. Por otros testimonios, sabemos que también se obtenía en el señorío de Aguilar, cáñamo y esparto ${ }^{52}$.

Se puede colegir que los cultivos en heredades y sembrados, es decir, en tierras de secano, siguen un régimen de campos abiertos, en tanto que las huertas e incluso las viñas próximas a las dehesas están cercadas. Probablemente la disposición de los cultivos estuviera hecha en un primer momento, al igual que en otras tierras de la Corona de Castilla, en una

"Ibidem, fols. 17 v. $-18 \mathrm{v}$.

$\because$ M.C. Quintanil.la Raso, op. cit., p. 231. 
especie de círculos concéntricos. En primer lugar, se encontraría quizás el área cercada de huertas; después, los campos abiertos dedicados al cereal y, junto a ellos, las viñas y los olivares -a veces siguiendo un sistema intercalar- y los baldíos; una tercera zona, de monte bajo, estaría preferentemente destinada para el aprovechamiento del ganado. Pero en el texto de las ordenanzas esta hipotética disposición de los cultivos, más propia de siglos anteriores, se omite. Sólo se habla del ruedo, es decir del espacio constituído en torno al núcleo de población donde los vecinos solían cultivar sus pequeñas y medianas parcelas, llamadas hazas. Un espacio que presumiblemente alcanzaría por término medio los tres kilómetros de distancia ${ }^{53}$.

En los títulos dedicados a la ganadería se observa que los animales más corrientes eran los puercos, bueyes, yeguas, vacas, ovejas, cabras, caballos, mulos y asnos. Los bueyes y vacas se utilizaban como animales de labor en las faenas agrícolas - cuatro por cada arado-. El caballo, en cambio, se empleaba exclusivamente como animal de guerra. Su tenencia era de antiguo sinónimo de prestigio y consideración social, máxime en una zona como ésta, fuertemente militarizada. Evidentemente, éstos son los únicos que aparecen mencionados en el texto de las ordenanzas, pero habría que incluir los animales salvajes y los de cría doméstica. La importancia que tiene la ganadería en el señorío de Aguilar es clara. Ello lo demuestra la rigurosidad con que se reglamenta este sector, que, además de estar presente en los capítulos referidos al cuidado de las tierras cultivadas tiene su propio y peculiar tratamiento en ciertos aspectos, tales como la pena de los ganados, el aprovechamiento y usufructo de las dehesas concejiles, la época en la cual los rastrojos pueden ser utilizados para pasto, el orden preferencial que se daba a las distintas clases de animales que debían de comerlos, etc.

Pero esa importancia en modo alguno se puede considerar nueva. En este sentido, convendría recordar que la Campiña fue durante mucho tiempo una zona fronteriza, lo cual contribuyó a fomentar entre sus habitantes el desarrollo de la actividad ganadera, porque el ganado en caso de ataque podía ser, por su movilidad, más fácilmente defendible. Y desde luego, las crónicas bajomedievales reflejan y celebran, a veces con exagerada intención, el número de cabezas obtenido por los contendientes en sus respectivas incursiones de saqueo. Además, la Campiña, área esencialmente cerealera, proporcionaba suficientes pastos para la ganadería, que, en todo caso, se mantuvo a distancia de la agricultura y en general probablemente como actividad complementaria de ésta.

Agricultura y ganadería, son, por consiguiente, los dos pilares básicos de la economía de los habitantes del señorío. Así lo evidencia el elevado número de disposiciones que a su reglamentación se dedica en estas orde-

s3 Ibidem, pp. 229-230. 
nanzas. Leeyes cuya finalidad básica es la de evitar posibles daños en las tierras cultivadas. Por ese motivo, se dictan rigurosas penas sobre los dueños o pastores del ganado que invada cualquier campo donde vegeten dichos cultivos; contra quienes corten hierba, frutos o plantas ajenas y un sinfín de normas más tendentes a favorecer la producción agrícola, que queda, en gran medida, vigilada por funcionarios públicos del concejo, los llamados guardas y mayordomos de campo.

No deja de ser interesante también conocer la clase de vegetación que se desarrolla en el suelo campiñés durante esa época, la cual responde, en general, al tipo xerofítico, propio de la España seca; dominan entre la arboleda la encina, el fresno y el álamo de ribera. El monte bajo y el matorral lo formaban una abundante gama de especies de tipo mediterráneo: el chaparro o carrasco, el lentisco, la jara, la coscoja, el jaguarzo, etc.

Igualmente, consta la existencia de zumacares, es decir, de plantas de cuyo fruto se extraía una sustancia, rica en tanino, que los zurradores utilizaban como curtiente. Parece que gran parte de esta vegetación era natural. Quizás el bosque de encinas se mantuviera igualmente en su forma originaria, sin sufrir aún el descuaje de plantas secundarias. Lo mismo podría pensarse del olivar, aunque no hay referencias claras a este respecto. Son muy pocas las noticias que nos proporcionan las ordenanzas, pero desde luego en ellas no se habla del acebuche, es decir, del olivo silvestre, sino sólo del olivo ¿el plantado y cultivado racionalmente?

La fauna espontánea nos resulta difícil de precisar. A través de las normas relativas a la caza se conoce la existencia de liebres, conejos, perdices y tórtolas, es decir, algunas de las especies más significativas de la caza menor. Sin embargo, no hay alusiones a otros animales que no sean lobos, cuya captura era económicamente recompensada. Tampoco se cita de la fauna piscícola especie alguna; cuando se habla de pesca o de venta de piezas en el mercado se utiliza la denominación genérica de "pescado", cosa que impide conocer las especies que poblaban los ríos del señorío -sólo se mencionan el Genil y el Monturque- a principios del siglo XVI. Pero en la dieta alimenticia de los habitantes del señorio también había productos silvestres, recogidos en los bosques y montes cercanos, miel, cuya producción se obtenía en los ruedos de las colmenas.

\section{a) Leyes de defensa y fomento de los recursos naturales}

Los apartados relacionados con el primer punto se encuentran todos ellos prácticamente recogidos en los títulos primero, segundo, quinto, séptimo y décimo de las ordenanzas antedichas. Son los de mayor interés e importancia a tenor del número de normas que contienen. En general están 
elaborados en defensa de la naturaleza. Pero, al mismo tiempo, lo que se quiere proteger es a los propios habitantes del señorío de las ingerencias de los forasteros.

Así, las normas recogidas en el capítulo primero se dedican a defender el arbolado de ribera existente junto a los ríos del señorío y a acotar la pesca en ellos para los vecinos del mismo. En general, las leyes se refieren al tipo de pena que se había de imponer a todos los que cortaran ramas y árboles -se citan fresnos y álamos prietos y blancos- de las riberas de los ríos Genil y Monturque sin permiso; la cuantía de la multa pecuniaria se fijaba en proporción al grosor de los árboles -no de las ramas-. Si el infractor era forastero perdía, además, las bestias y herramientas utilizadas en la tala y acarreo de la madera, que, una vez recuperada, debía ser empleada en la construcción o quemada, si era menuda, en el hospital del lugar en cuyo término se hubiera cometido el delito ${ }^{54}$. Sin embargo, no siempre se cobraban las multas. Y ello era así por defecto de forma y orden del proceso judicial, cuyo alargamiento dejaba prácticamente impunes a quienes contravenían la norma. A fin de corregir este hecho y evitar la destrucción y tala indiscriminada de los árboles, los señores de Aguilar daban un plazo de treinta días a los guardas u oficiales del campo para realizar la pertinente pesquisa y averiguar el autor $-\mathrm{O}$ autores- de la infracción siempre que no lo hubiera visto hacer el daño. En estos casos, el guarda tenía que presentar un testigo ocular de los hechos de más de catorce años para demostrar con su juramento la culpabilidad del delincuentess.

5.4 "Por quanto la conservaçión delos árboles delos ríos de Xenil e Monturque y delos otros de nuestro térmyno es muy nesçesaria, hordenamos e mandamos que ninguna persona vesino ny morador delas villas de Aguilar y Montilla, la Puente Don Gonzalo e Monturque e Montalván ny de fuera parte de qualquyer condiçión que sea no sean osados de cortar ny corten en los dichos ríos ny en alguno dellos ny en qualquyer manera árbol grande ny pequeño ny rama ny otra cosa delos dichos árboles sin nuestra espresa liçençia que se entiende fresnos y alamos prietos y blancos que en los dichos ríos y sytios dellos aya e pueda aver so pena que si el árbol fuere tan grueso commo la pierna yncurra el que lo cortare en pena de seysçientos marauedís e sy fuere menor pie trezientos marauedís y por cada rama de qualquyer gordura o tamaño que sea çinquenta marauedís y delas dichas penas sea la terçia parte para el conçejo e todo lo demás para la guarda e mayordomo del campo o regidor o jurado o mayordomo de conçejo o alcalde o ofiçial público que lo tomare e denunçiare y prouare y siendo vesino de fuera parte que demás dela dicha pena pierda las bestias y herramientas o la estimaçión dello y en el un caso e otro la madera sea y se traiga para nuestras obras e sy fuera menuda para quemar se dé y traiga e se aplique al ospital dela villa o lugar donde fuere la guarda o ofiçial público que lo tomare o denunçiare e prouare que más nesçesidad tenga dela dicha leña y que la guarda o qualquyera ofiçial público delos de suso contenydos que viere el dicho daño sea creydo por su juramento e se aya por entera e llena prouança» (ADM, Priego, 14-16, fols. 19 r. -19 v.).

ss ADM, Priego, 14-16, fols. 19 v.-20 v. 
El procedimiento judicial seguido a partir de la denuncia hecha por el guarda ante el escribano y el juramento de éste o del testigo que vio el daño era el siguiente: El juez daba al alguacil mayor la orden de captura. El infractor, citado a declarar, recibía copra notarial del auto interpuesto contra él y tenía seis días para probar su inocencia. Entre tanto, y para asegurar la recaudación de la pena, se sacaba en almoneda una o varias de sus prendas. Finalizado ese plazo, el juez debía dictar sentencia. Si la persona retenida era declarada culpable debía de pagar la correspondiente multa y las costas del proceso y la prenda que el alguacil mayor sacó de su casa quedaba en poder de la persona que la compró en la subasta. Sin embargo, todavía podía apelar en segunda instancia y probar su inocencia. En este caso, al juez correspondía deshacer el agravio.

Los vecinos necesitaban también licencia del concejo para recoger la madera o leña seca encontrada en el suelo junto a los árboles a orillas de esos ríos. Pero para obterner ese permiso debían de jurar que no cortaron la madera que solicitaban ni conocían la identidad de quien lo hizo. Las personas que delinquían en estos casos debían pagar multas de sesenta maravedís". Una parte de las cantidades provenientes de las multas se daba a los guardas y oficiales de las villas y lugares del señorío que habían presentado la denuncia. El cobro del importe correspondiente de la caloña motivó a veces desavenencias entre los guardas y oficiales de las diferentes villas y lugares del señorío, que recíprocamente declaraban haber visto y probado con testigos el delito primero.

Los titulares de la casa de Aguilar determinaron acabar con esos debates porque eran origen de largos procesos judiciales y propiciaban el descuido en la vigilacia del cuidado de los árboles. Así, dispusieron que el beneficiario de la pena debía de ser aquel que primero denunciara el delito al escribano del concejo o ante otro notario público y dos testigos. Ese escribano debía de anotar el día, mes y año de la denuncia, así como el nombre de las dos personas que habían servido de testigos. En caso de que el guarda no hubiera visto personalmente el daño, cobraba la pena quien

s6 "Hordenamos y mandamos que si alguna madera o leña seca se hallare en el suelo çerca delos dichos ríos que no sea de prouecho ny pueda ser más de para quemar que los vesinos delas dichas villas y lugares no la puedan llevar syn liçençia del conçejo donde fuere el que la llevare de alguna destas dichas villas e lugares so pena de sesenta marauedís, la mytad para la guarda o ofiçial público que lo tomare e denunçiare e la otra mytad para el conçejo y que quando el conçejo oviere de dar la tal liçençia jure el que la pidiere que no cortó ny fue en cortar la leña seca que pide ny sabe quien la oviese cortado y que de otra manera no se le dé la dicha liçençia e si la madera fuere de prouecho que sea para nuestras obras y que no se pueda dar liçençia para ella y el que la llevare yncurra en la dicha pena delos dichos sesenta marauedís" (ADM, Priego, 14-16, fols. 20 v. -21 r.). 
primero presentara un testigo del hechos". También en ese título primero existe una norma que prohibe a los forasteros pesiar en los ríos del señorío con más de un anzuelo; en este caso, el infractor, además de perder los aparejos de pesca, debía de abonar el pago de una multa, cuya cuantía -sesenta maravedís- se reservaba para el guarda que hizo la denuncia ${ }^{5 x}$.

En el título segundo, más amplio y diverso que el anterior, hay una serie de leyes, cuyo contenido básico es la protección de la flora y fauna del territorio y la utilización de ciertos aprovechamientos naturales: "Mucho conviene entenderse sobre la guarda e conseruaçión delos montes que son tan nesçesarios para el uso común" ". Esta frase resume perfectamente el espíritu de todas esas normas. Una de ellas, por ejemplo, impone multas muy variadas a quienes cortasen encinas y chaparros en los términos de las villas y lugares del señorío: seiscientos maravedís por cada pie de encina o chaparro y el diez por ciento de esa cuantía por cada rama talada. La prohibición afectaba tanto a vecinos como a forasteros. Sin embargo, estos últimos eran más fuertemente penalizados, pues además de pagar la tasa correspondiente a la gravedad del delito perdían las bestias o su estimación.

La defensa que se hace del encinar en estas ordenanzas es particularmente notoria y superior a la de otras especies árboreas, porque su cuidado beneficiaba la producción de la bellota, alimento básico para el ganado. Y esa diferencia queda plasmada en el distinto valor de la pena, que en el caso de lantiscos, jaras, coscojas y guarzos, por ejemplo, se reduce a doscientos maravedís o a la mitad si el infractor era sorprendido en el camino por el guarda, o cualquier otro vecino del pueblo de más de catorce años, llevándose la leña. En cambio, la corta de ramón, generalmente realizada por cabrerizos y ganaderos, en los árboles y alamedas, encinas y chaparros, se penaliza también con seiscientos maravedís o con sesenta si fuera ramón de la ribera, de encina "cabdal» o de chaparros pequeños ${ }^{(0)}$. En los casos que el

57 ADM, Priego, 14-16, fols. 21 r. -21 v.

is "Hordenamos y mandamos que ninguna persona de fuera parte no entre a pescar ny pesque en los dichos ríos ny en los otros desta nuestra tierra so pena de sesenta marauedís para la guarda o ofiçial público que lo tomare e los aparejos perdidos para la dicha guarda o público ofiçial y que sea creydo por su juramento y si el pescador no [fuere] con más de anzuelo que no yncurra en pena porque a este tal damos facultad y liçençia que pueda pescar» (ADM, Priego, 14-16, fol. 21 v.).

(9) ADM, Priego, 14-16, fol. 22 r.

(x) «Hordenamos y mandamos que qualquyer cabrerizo o ganadero o qualquyer otra persona que cortare ramón delos árboles o alamedas o enzinas o chaparros canperos yncurra en pena de seysçientos marauedís si el tal ramón fuere dela ribera o de enzina cabdal e si fuere de chaparros pequeños que pague de pena sesenta marauedís y que la guarda o ofiçial público sea creydo por su juramento y dela dicha pena sea la terçia parte para el conçejo e lo demás para la guarda o ofiçial público que lo tomare o denunçiare o provare y en el proçeso y execuçión dela dicha pena se guarde la forma que se contiene en el dicho título primero delos ríos de xenil e de Monturque en la ley segunda" (ADM, Priego, 14-16, fols. 22 v.-23 r.). 
delite no tuese directamente contemplado por el guarda, éste debía de prosbarlo en el plazo de un mess.:

En las tierras del señorío exastía la costumbre de aprovechar la festividad del día de Todos los Santos (primero de noviembre) para ir a coger bellota; la gente se iba muy temprano, incluso de noche, a los encinares y en ellos permanecía durante toda la jornada, con lo cual dejaban de asistir a misa y quebrantaban esa fiesta religiosa, "de mucha veneraçión e gran solemnydad y de muy gran prouecho para satistaçión delo que por todo el año se ha olvidado e omitido", que tenía un acusado carácter penitencial. Los señores de Aguilar, sin embargo, decidieron romper esa antigua práctica en favor de la devoción religiosa y ordenaron que tanto los concejos como los vecinos y moradores de las villas y lugares del señorío fuesen en lo sucesivo a recoger la bellota el tres de noviembre, es decir, después del Día de los Difuntos, porque también la Iglesia acostumbraba "çelebrar conmemoraçión por los finados" "'?

Hasta tanto llegaba esa fecha, los encinares permanecían acotados. La pena establecida para quienes cogieran bellotas los días de fiesta antedichos variaba según incurriese en ella el concejo-mil maravedís, descontados de los bienes personales de sus oficiales, la mitad de ellos para la iglesia mayor del pueblo-o los vecinos -doscientos maravedís-. En cambio, la multa por

(1) ADM, Priego, 1.4-16, fol. $23 \mathrm{r}$.

1: "Costumbre avía en esta tierra de se desacotar la bellota delas dichas villas e lugares el día de Todos Santos, el qual día los conçejos yvan comúnmente a recoger y commo sea la fiesta de Todos Santos de mucha veneraçión e gran solemnydad y de muy gran prouecho para satısfaçión delo que por todo el año se ha olvidado e omitido que aquel día se pese doblado y no es rasón que tan gran bien se prenda por coger bellota en espeçial que la gente va de mañana o de antenoche por tomar enzinas y pierden la misa del día y se quebranta la fiesta de muchas maneras ansí por esto commo por el trabajo continuo del día hordenamos estableçemos y mandamos que de acjuí adelante los conçejos delas dichas villas e lugares ny alguno dellos ny otras personas particulares no se atreuan a desacotar ny desacoten la dicha bellota ny la vayan a coger ny cojan en el dicho día de Todos Santos ny en el otro día siguiente porque la Santa Madre lglesia acostumbra fazer y çelebrar conmemoraçión por los Finados e no es bien que se pierdan tales dos fiestas ny la deuoçión dellas. E mandamos que la bellota se desacote en toda esta nuestra tierra e por esta hordenança la desacotamos para los vesinos e moradores delas dichas villas e lugares el primero día siguiente que no sea de fiesta pasados los dichos dos días de Todos Santos y delos Finados e que ansí se faga e cumpla so pena de cada mill marauedís a cada conçejo que lo contrario hiziere o diere lugar o no proueyere que ansí se haga e cumpla, la mytad para la iglesia mayor dela villa o lugar e la otra mytad para nuestra cámara y que la dicha pena paguen los ofiçiales de conçejo de sus bienes e no delos bienes del conçejo e los otros vesinos e personas particulares yncurran en pena de cada dozientos marauedís, la mytad para el conçejo donde fuere la guarda o ofiçial público que lo tomare e la otra para la tal guarda o ofiçial público y que sea creydo por su juramento y en la execuçión delas penas se proçeda segúnd que está dicho en la ley segunda, título terçero» (ADM, Priego, 14-16, fols. 31 r.-31 v.). 
golpear la encina y coger su fruto en tiempo vedado era, si se tenía el ganado junto a ella, de seiscientos maravedís. La multa se exigía a quienes en ese momento tuvieran la vara arrimada al árbol o en el suelo, siempre, claro está, que hubiese vestigios en la tierra o en la encina que se vareó. Como suele ser habitual en la casuística contemplada en estas ordenanzas, los forasteros, además de abonar el dinero de la pena, perdían los animales de carga y los aparejos. No obstante, podía ocurrir que la persona fuera tomada en el campo llevando más de medio almud de bellotas sin que tuviera el ganado próximo a las encinas. En ese caso se le sancionaba con 6() maravedís, el doble si se trataba de un forastero" ${ }^{(2)}$.

Por otra parte, era igualmente penalizado el ganadero o pastor foráneo que era sorprendido con los animales dentro de los términos de las poblaciones del señorío. Cuando ello sucedía, la multa se cifraba en el quinto del ganado, del que se hacían dos mitades, una para el concejo y otra para el guarda o vecino que denunció la intromisión; y si se tomaba pastando en heredades y campos de cereal, aquéllos debían de pagar, además de la pena del quinto, el daño al propietario de los cultivos": Y porque las dichas nuestras villas e lugares tienen vesindad con algunos conçejos e villas dela comarca sobre las penas delos dichos térmynos e sobre otras cosas queremos y mandamos que las dichas vesindades se conserven e guarden en aquello que está capitulado y asentado y se a usado e guardado de tiempo antiguo e si nesçesario es confirmamos y aprouamos las dichas vesindades por quanto fuere nuestra voluntad ${ }^{(64}$.

Mucho cuidado pusieron también los señores de Aguilar en regular el tema de los fuegos para evitar incendios y daños en los montes, eriales y sembrados. De hecho, estaba terminantemente prohibido con pena de seiscientos maravedís encender fuego en el campo sin la autorización del concejo durante los meses estivales, entre la festividad de San Juan (24 de junio) y la de San Miguel (29 de septiembre). Los fuegos en las heredades estaban igualmente castigados; la multa recaía en los dueños de ellas, siempre que no pudieran probar su inocencia. Si el incendio lo ocasionaba alguno de sus criados o hijos, quedaba del mismo modo obligado al pago de la pena ${ }^{65}$. La

hi ADM, Priego, 14-16, fols. 31 v. -32 r.

(n) Ibidem, fol. $23 \mathrm{v}$.

os «Mandamos y hordenamos que dende el día de San Juan del mes de junio de cada un año hasta el día de San Miguel del mes de setiembre ninguno ençienda fuego en monte ny campo sin liçençia del conçejo firmada del escriuano del dicho conçejo so pena de seysçientos marauedís, los quatrosientos para el conçejo y los dozientos marauedís para la guarda o ofiçial público que lo viere y tomare o prouare y que basta ençenderse fuego en una heredad para que el dueño de aquella heredad sea obligado a la dicha pena si no provare legítimamente quien lo hizo que sea persona estraña de cuyo hecho no sea obligado y declaramos que si su moço o hijo o siervo oviere puesto el tal fuego que sea el señor o padre obli- 
quema de restrojos y de eriales debía de hacerse a partir de Santa María de Agosto ( 15 de ese mes). El infractor de la norma tenía que pagar doscientos maravedís, y, además, el daño ocasionado, establecido en ciento veinte por cada aranzada quemada. Al concejo no le estaba permitido expedir licencias de quema de restrojos antes de la fecha referida. Sin embargo, podía otorgarlas desde el día dieciseis siempre que la solicitud se hiciera en el cabildo ${ }^{(x)}$. El permiso así concedido tenía que llevar la firma del escribano del concejo. Se consideraba innecesaria su petición cuando el fuego se hacía dentro del tiempo referido al final de las eras, o en riberas y barranqueras, a sesenta pasos en el interior del barbecho y en una extensión de seis palmos de ancho por seis de fondo. Por lo demás, todos debían de apagar el fuego realizado para guisar"?

Los marqueses de Priego aprobaron también el valor de las penas contra quienes entraban de otros lugares del señorío sin licencia en sus términos a coger "alcaparra o mostaza, junco, junçia o enea o cardos o esparragos e alcachofas o hongos o setas turmas o otras cosas de aprouechamiento de qualquyer naturaleza» y eran sorprendidos "in situ» en esa tarea o transportando los frutos de su recoleciión. Se contempla el pago de una multa -sesenta maravedís por cada animal que llevare consigo- y la pérdida de las herramientas utilizadas ${ }^{(18 .}$.

gado a la pena y que la pueda contar al moço en la soldada o al hijo en la ligítima. E qualquyera que quemare erial pague por cada arançada çiento e veynte marauedís e mandamos que qualquyera que tuviere fogariel (abo su hera lo a de tener sesenta pasos dentro en el barbecho y tenga seys palmos en hondo y otros seis en ancho y esto mysmo se eníenda en ribera o varranquera y hasiéndose desta manera no sea menester pedir liçençia para los fogariles y acabando de guisar de comer apaguen el fuego e no fíen los eslabones delos moços ny muchachos so pena de cada sesenta marauedís por cada vez, la mytad para el conçejo y la otra mytad para el que lo denunçiare e tomare y en la execuçión destas penas se guarden la forma e horden que se contiene en la dicha ley segunda título terçero delos estableçimientos y hordenanças desta segunda parte» (ADM, Priego, 14-16, fols. 33 v.- 34 r.).

(6) ADM, Priego, 14-16, fol. $34 \mathrm{r}$.

6. Ibidem, fols. 33 v. -34 r.

ox "Otrosy hordenamos y mandamos que qualquyer persona de fuera parte que entrare sin nuestra liçençia en los dichos térmynos a coger alcaparra o mostaza, junco, junçia o enea 0 cardos o esparragos e alcachofas o hongos o setas turmas o otras cosas de aprouechamiento de qualquyer naturaleza que no sea delas cortas espresadas en algunas delas nuestras hordenanças porque en ellas está la pena que se yncurre pague de pena por cada bestia que trajere sesenta marauedís y pierda las herramientas y que aya lugar la dicha pena aunque la guarda o ofiçial público o vesino o hijo o moço de vesino no vea estar cojiendo los dichos aprouechamientos e baste tomarlo cargando o yendo cargado con la tal cosa dentro del térmyno no prouando el forastero que lo cojió fuera del térmyno y que sin pena ny calupnia alguna pueda ser prendado por las dichas personas e por cada una dellas y que sea creydo por su juramento el que lo tomare o viere en la pena conforme al thenor desta hordenança. E otrosy que el vallestero o caçador que entrare en los dichos térmynos sin nuestra liçençia que pierda la ballesta e la caça que tuviere y delas dichas penas sea la mytad para el conçejo y la otra mytad para quien lo tomare o viere o denunçiare o provare» (ADM, Priego, 14-16, fols. 23 v.-24 r.). 
Cuando se trataba de un cazador, éste perdía no sólo la ballesta o los galgos, perros y aparejos que empleaba, sino también toda la caza -se cita conejos, liebres, perdices y tórtolas-. Igualmente, se le obligaba a pagar sesenta maravedís de pena ${ }^{(t)}$. Pero en el tema de la caza, además de castigar la posible intromisión de forasteros, se quiso proteger a determinadas especies objeto de las capturas, siguiendo, en este sentido, la legislación aplicada en el reino castellano. Así, se prohibió utilizar lazos de alambre -se imponía una pena de doscientos maravedís, doblada e incluso triplicada, en caso de sucesivas reincidencias, junto a la sustracción del instrumental ${ }^{71}-\mathrm{y}$, además, hurones - desde el día de Pascua Florida hasta el día de San Miguel (29) de septiembre) de cada año- ${ }^{-1}$.

Otros dos temas regulados en las ordenanzas guardan relación con la extracción de minerales en el territorio del señorío. Uno se refiere a las salinas, el otro a las canteras. Las primeras eran del concejo, aunque podían ser arrendadas a los salineros para su explotación. Las ordenanzas de 1519 sólo mencionan dos salinas, la de Masgallín, perteneciente al concejo de Aguilar, y la de Malabrigo, del concejo de Montilla. La producción de la primera servía también para abastecer, en la forma acostumbrada, a los vecinos de La Puente Don Gonzalo, Monturque y Montalbán. El robo de la sal se castigaba con multas de seiscientos maravedís y pérdida de las bestias y aparejos para los forasteros ${ }^{72}$. Sacar piedra del término era también motivo de sanción. La persona tomada llevando piedra menuda en asnos o en carretas pagaba por cada carga del material doscientos maravedís; si la piedra era para molino o aceña o bien piedra de barbero, perdía igualmente los bueyes $^{73}$.

69) ADM, Priego, 14-16, fol. $24 \mathrm{r}$.

7) "Hordenamos y mandamos que ninguna persona vesino ny morador destas dichas villas e lugares ny de fuera parte no caçen con lazos de arambre en estos térmynos so pena de dozientos marauedís por la primera vez y por la segunda quatrosientos marauedís y por la terçera seysçientos e si fuere de fuera parte pague por cada vez seysçientos marauedís y los aparejos perdidos, la mytad destas penas para la guarda o ofiçial público o qualquyer otra persona vesino, moço o hijo de vesino que los tomare y la otra mytad para el conçejo y que sea creydo por su juramento el que los tomare y que se proçeda para la execuçión destas penas segúnd que se dixo en lo delas cortas delos árboles delos dichos ríos declaramos y mandamos que al vesino no pueda penar syno la guarda o ofiçial público e no otro vesino ny moço ny hijo de vesino syno al forastero e ansy se entienda esta ley e se guarde" (ADM, Priego, 14-16, fol. 25 r.).

ADM, Priego, 14-16, fol. 25 v.

72 Ibídem, fols. 24 r. -24 v.

73 "Hordenamos y mandamos que ninguna persona de fuera parte lleve piedra menuda en asnos ny en carretas e si fuere tomado e visto e prouado que pague por cada carga de piedra dozientos marauedís e sy fuere piedra para molino o açeña o piedra de barbero demás dela dicha pena pierda los bueyes e la carreta en que la sacare y la mytad dela dicha pena sea 
Tambien era frecuente que el torastero ante la llegada del guarda o de algún vecino del pueble se diera a la fuga llevándose, a veces, lo robado, o se resistiese y lo defendiera haciendo uso, o no, de sus armas. Ello, como es obvio, repercutía negativamente en los vasallos del señorío, que se veían sustraídos de una parte de los recursos naturales que se generaban en el término de sus pueblos. Pero también perjudicaba a la propia justicia que se ejercia dentro del estado. Por ello, los marqueses establecieron un plazo de dos años para que los guardas y demás personas autorizadas a penalizar y a prender a esos forasteros pudieran cumplir con ese derecho. Más allá de ese tiempo, la pena quedaba prescrita ${ }^{-}$.

\section{b) Ordenanias de protecición a los sembrados}

En primer lugar, nos encontramos con una preocupación general, la relacionada con la salvaguarda de las heredades y sembrados frente a la entrada en ellos de ganado. Es decir, con el derecho del agricultor frente al del ganadero, temas que tienen, sin embargo, un tratamiento distinto en cuanto a la estimación de las penas, según afecten a vecinos de diferentes villas o a los habitantes de un mismo término. Dentro de las heredades se incluyen las viñas, las huertas y los olivares. En los sembrados, únicamente los campos de cereal. La mayor vulnerabilidad y cuidado que exigen los productos hortícolas, las uvas y las aceitunas, determina en gran parte que las multas por el posible daño que se haga a estos cultivos sean sensiblemente superiores a los de secano. Además de los cultivos, se puede perfectamente colegir el proceso seguido en la explotación del suelo de secano. A mediados de marzo termina la siembra, entre esa fecha y el mes de junio maduran las mieses. A continuación se siegan los campos. Los rastrojos se aprovechan para alimentar al ganado porcino y a bueyes, animales éstos de labranza, al menos hasta el 15 de agosto, fecha a partir de la cual se inicia su quema.

La norma que se refiere a la pena de las heredades establece una clara dicotomía entre sus dos núcleos rurales más importantes, Aguilar y Montilla, y a la vez, incluye dentro del término del primer pueblo citado a La Puente Don Gonzalo, Monturque y Montalbán. Estos lugares, pues, per-

\footnotetext{
para el conçejo e la otra para la guarda o ofiçial público o vesino o hijo o moço de vesino que lo tomare o denunçiare e prouare e que cada uno dellos sea creydo por su juramento e baste por entera provança. E otrosy que ningúnd vesino dela villa o lugar saque las dichas piedras de barbero o para molino o açeña para llevar a vender fuera parte sola dicha pena. El proçeso se haga sobre las penas desta hordenança segúnd que es dicho en las cortas delos árboles delos ríos" (ADM, Priego, 14-16, fols. 24 v.-25 r.).

ADM, Priego, 14-16, fols. 25 v.-26 r.
} 
tenecen al dominio jurisdiccional de Aguilar. Por ese motivo, la salina de Masgallín, ubicada en el término de la villa antedicha, abastecía únicamente a tales poblaciones. Esa diferencia queda también reflejada en la ley que ahora comentamos, la cual trata, según se dijo, de las penas que se imponen a esos vecinos cuando sus ganados invaden tierras ajenas. Las cuantías de las multas están fijadas en proporción a la clase del ganado: la pena pecuniaria es más elevada cuando se trata de ganado mayor (vacuno y caballar). Aún así dentro de este grupo existe un tratamiento desigual respecto a la valoración de las multas, quizás en función del estropicio que la condición natural de una u otra bestia pudiera ocasionar. En ambos casos, sin embargo, no se penaliza al animal que sigue a la madre.

Así, por un buey o una vaca se pide de pena veinte maravedís; por una yegua o cualquier otra bestia caballar treinta; y, si no hubiere esquilmo, por el asno y el puerco cinco y dos por la oveja y la cabra. El guarda era el beneficiario del pago de esas tasas y estaba obligado a comunicar el hecho al propietario de la heredad, que podía también, siempre que tomase el mismo el ganado en su tierra, escoger entre cobrar el importe establecido en aquel peaje o percibir el dinero tasado por la evaluación del mal recibido. Pero si el ganado entraba de una sola vez en varias heredades únicamente se pedía la tasa correspondiente del peaje, la cual podía ser para el guarda o para el dueño, según quien los denunciara. Los demás señores sólo obtenían el aprecio hecho del destrozo.

También se castigaba, según se dijo, la entrada del ganado en los sembrados, pero el importe de las penas era notablemente inferior al cobrado en otro tipo de explotaciones. En las tierras de secano, donde se cultivaba preferentemente trigo, cebada, escaña, jarvanzo y centeno, el montante de las cuantías era el siguiente: por cada yegua y res vacuna diez maravedís, por el asno tres y por la manada de ovejas, cabras o puercos, doscientos; pero si ésta estaba formada con menos de sesenta animales, se debía pagar por cada uno de ellos un maravedí. La pena podía pedirla el dueño del sembrado a partir de mediados del mes de marzo, es decir, desde el momento en que iniciaba la siembra. Como en el caso anterior, ese propietario, si había sido él el denunciante, podía elegir entre cobrar la cantidad arriba mencionada, según el tipo de ganado que hiciera el daño, o el dinero estimado por el estropicio después de haberlo probado con un testigo de catorce años arri$\mathrm{ba}^{75}$.

En los pleitos que pudieran suscitarse entre labradores propietarios de cortijos, o entre aparceros, los señores de Aguilar disponen que se respeten los acuerdos establecidos entre ellos en cuanto a las penas y daños. Entre los aparceros se contemplan las siguientes penas: Por el puerco una blanca y

ADM, Priego, 14-16, fols. 32 r.- -32 v. 
por el asno un maravedí si entran en la heredad de día, dos cuando es de noche. Vacas, bueyes, caballos y yeguas dos maravedís (tres por cabeza si el daño lo hacen de noche). Las multas del peaje las pueden cobrar los mayordomos del campo y guardas u oficiales públicos, pero nol las demás. Se establece una fecha clave, la de mediados del mes de marzo. Antes de ese tiempo, el dueño del sembrado podía percibir dichas multas si había tomado el ganado en su tierra. Después de ese día cobraría por el daño, según la valoración que se hiciera, porque a partir de entonces se realizaba la sementera. Por lo demás, al pastor o ganadero que llevara los animales a comer por la linde de los panes y anduviere con ellos dentro del sembrado haciendo camino se le sancionaba con multa de seis maravedís y si "alguno no quisiere entrar en el aparçería ny hechar su ganado al ganadero del tal cortijo que sea apremyado a ello por la mayor parte delos labradores del tal cortijo y le puedan quitar su renta si quisieren y repartirla entre ellos y pague la pena doblada" ".

En la ordenanza se establece también el procedimiento a seguir en el proceso de la ejecución de las penas antedichas: Primero, el guarda o el dueño de la tierra entregaba al propietario del ganado o al ganadero personalmente o en su casa una sola citación. Ese mismo día o al siguiente ponía la demanda ante el juez el pueblo, juraba haber sorprendido a esos animales en la tierra cultivada y solicitaba cobrar la cuantía correspondiente del peaje. El alcalde, a su vez, daba mandamiento para obtener del infractor una prenda, al cual le concedía un plazo de tres días para alegar y probar su inocencia o descargo. Concluído ese plazo, el juez dictaba la sentencia y al día siguiente ordenaba pregonar tres veces que se iba a subastar aquella prenda, la cual quedaba para siempre en poder del mejor postor, independientemente de que después el acusado apelara la resolución de la causa en segunda instancia ${ }^{77}$.

Cuando el señor o señores de las heredades y sembrados querían conseguir la restitución del daño se guardaba la forma siguiente: por una citación también emplazaban al dueño del ganado. En el mismo día o al siguiente de la citación interponían la correspondiente denuncia ante el juez y pedían las costas de los daños sufridos. Si la parte acusada estaba presente debía de declarar su inocencia o culpabilidad en el hecho que se le imputaba. En todo caso, el juez debía de concluir el pleito al día siguiente y dar tres días de plazo a las partes para probar sus respectivas alegaciones. Entre tanto, el juez, a petición del labrador o aparcero, enviaba a la heredad dañada a personas competentes para estimar y valorar la magnitud de la destrucción. El informe realizado por esos "peritos» debía de estar en su

${ }^{76}$ Ibidem, fol. $32 \mathrm{v}$.

Ibidem, fols. 26 v. -28 r. 
poder en el plazo ya fijado. En esos días, el propietario o tenente de la tierra cultivada debía igualmente de probar con un testigo -podía ser un vecino o un hijo o criado de vecino de catorce años-el hecho que denunciaba.

Al día siguiente de acabado el plazo asignado se publicaba el nombre del testigo y se concluía la causa. Uno o dos días más tarde, el alcalde tenía la obligación de emitir sentencia conforme al aprecio del daño, si es que el ganadero resultaba culpable, siguiéndose el procedimiento empleado en el tema del peaje. Podía suceder que el dueño o tenente de la tierra descubriese el estrago pero no a quien lo hizo. En estos casos, pedía al juez que mandara apreciadores a su propiedad. Estos, mediante juramento, comunicaban la evaluación del daño al alcalde y su estimación la recogía el escribano hasta saber la autoría de la persona que causó con el ganado el mal. Para ello, se seguía la costumbre de aplicar el criterio de cercanía, según el cual se responsabilizaba de la culpa al ganadero o pastor cuyo ganado se encontrase en ese día más próximo al lugar de los hechos, siempre que no denunciara al autor del daño y sus animales fueran de la misma condición y rastro de los que causaron el perjuicio.

En ese sentido, la ley es bastante clara: "si el rastro del ganado que hizo el dicho daño fuere de vacas o bueyes y el ganado que se hallare çerca fuere yeguas o ovejas o otro ganado no se presuma que hizo el daño ny sea obligado a dar quien lo hizo" ${ }^{7 *}$. Pero, si no era así, el ganadero, si quería evitar ser inculpado, tenía que denunciar al autor del daño y para ello debía de presentar el mismo día del hecho un testigo que diera credibilidad a su testimonio. Ahora bien ese testigo tenía que reunir una serie de requisitos: ser mayor de edad y no tener ningún grado de parentesco y de dependencia laboral con el denunciante. Todavía, el ganadero condenado por el sistema antedicho tenía el plazo de un mes para demostrar su inocencia ante el juez ${ }^{79}$.

\section{c) Disposiciones sobre los ganados, dehesas y rastrojos}

Esta serie de normas ponen de manifiesto la existencia en tierras del señorío de Aguilar de diversas dehesas para pasto del ganado. Conocemos a través de esas ordenanzas que los animales de labor podían pastar en las dehesas concejiles y en los ejidos de los cortijos. En ellas estaba prohibida la entrada de ovejas, cabras y puercos. La pena que debía de satisfacer quien contraviniere la ley, aplicada incluso a los oficiales del concejo, era de doscientos maravedís por manada o de un maravedí por cabeza si el número de

78 ADM, Priego, 14-16, fol. 38 v.

7) Ibidem, fols. 38 v. -39 r. 
los animales no llegaba a sesenta, descontando al ganado que mamare y anduviere tras la madre.

A juzgar por el contenido de las ordenanzas, la mayor parte de las dehesas pertenecian al concejo de Montilla, en cuyo término se encontraban al menos cuatro de las que debía de haber en el conjunto de las tierras del señorío. Esas dehesas se llamaban Huelma, Panchía, Nueva y Vieja. La primera estaba limitada sólo a caballos, potros y bueyes de acarreo(s). La segunda, en cambio, era para los ganados pertenecientes a los carniceros de aquella población. No obstante, se permitía la entrada a los animales de labor de todas las villas y lugares próximos a la dehesa, cuatro por cada arado, cuando se efectuasen labores en el campo, en días de fiesta y durante la Pascua y cuando dejasen de labrar a causa de la lluvia ${ }^{x l}$. La dehesa Nueva la compró el concejo montillano a ciertos vecinos para uso exclusivo de caballos y de asnos; también podían pastar en ella borricos, potros y becerros menores de un año. Si hubiese yegua o res vacuna de mayor edad, su dueño debía de pagar por ella diez maravedís; tampocose podía aparear el ganado caballar ni entrar animales de cortijos. En cambio, los bueyes y vacas de arado, en tanto se utilizaban para labrar olivares, viñas, hazas de alcacer y zumacales, estaban autorizados a comer en la dehesa ${ }^{x 2}$. La última, la llamada dehesa Vieja solía servir de ejido para todos los ganados de la villa, salvo para los puercos, ovejas, cabras y yeguas ${ }^{x}$. En las ordenanzas que ahora se promulgan se admite, en cambio, que esos animales puedan permanecer en esa dehesa por espacio de seis días. Quedan excluidos los ganados de los carniceros.

Por otra parte, para evitar daños innecesarios en todas las dehesas, los señores de Aguilar ordenaron que se quitaran las zaburdas hasta entonces existentes en ellas y no se hiciesen otras nuevas, si bien mantuvieron las porquerizas en determinados sitios, como en el Pozo de Malabrigo y en la Fuente El Cerrillo de la Vereda, junto al camino que iba a Espejo, topónimos ambos de fácil localización, o en el lugar donde el concejo de Montilla estaba haciendo una zahurda, en el camino que iba a Santa Brígida, desde el final de La Fuente de Fray Alonso hasta dar en la encina de El Rastro ${ }^{84}$. También dispusieron que no se sacaran cepas de las dehesas, infracción que se castigaba con multa de cien maravedís. Por último, en el término de Montilla había una vereda, ancha y delimitada, que utilizaban los pastores que se dirigían con sus ganados a la dehesa Nueva. Pues bien, el uso de ese

\footnotetext{
*) ADM, Priego, 14-16, fol. 29 r.

8) Ibidem, fols. 29 r.-29 v.

$x:$ Ibidem, fols. 29) v.-30 r.

*i lbidem, fol. 3() r.

A.t ADM, Priego, 14-16, fol. 30 v.
} 
camino estaba igualmente reglamentado: no podían pernoctar en él cabras ni ovejas, y sólo se autorizaba a hacerlo por una noche a las ovejas de paso en un lugar muy concreto, al final de la vereda, encima de La Fuente de la Higuerass.

Inmediatamente después de la siega, los rastrojos eran comidos por los puercos. Lo que quedaba se acotaba durante ocho días sólo para los bueyes de arada $y$, si en ese tiempo se encontraba en el lugar ganado ovino o cabras, su propietario o ganadero tenía que pagar doscientos maravedís o uno por cabeza si no se consideraba manada. El importe de la pena se dividía a medias entre el guarda y el concejo, o entre éste último y el labrador o aparcero que lo denunciare. Pero el dueño del rastrojo podía convertirse en el único beneficiario de la multa en caso de denunciar y probar con un testigo él mismo el hecho ${ }^{\text {th. }}$. Estaba expresamente prohibido de acuerdo con una práctica antigua vender los rastrojos para alimento de ovejas, cabras o carneros. De hecho, se penalizaba con doscientos maravedís al vendedor ${ }^{\gamma>}$.

\section{d) Leyes para los ruedos}

En los ruedos de las villas y lugares del señorío, es decir, en los espacios dedicados al cultivo, y, también en las dehesas de uso exclusivo de los carniceros, consideradas en el texto de estas ordenanzas como ruedos, caso de Montilla, estaba prohibida la entrada de puercos, ovejas y cabras. Sin embargo, estaba permitida la presencia del asno, "porque los asnos pueden andar en los ruedos e dehesas sin pena" y la del ganado vacuno empleado en la labranza, limitado a cuatro bueyes por arado en viñedos y olivares. La protección de los cultivos era notoria. Los puercos y cabras cuando se sacaban de las villas y lugares debían obligatoriamente de seguir los caminos y veredas acostumbrados. La vigilancia de los ruedos generalmente la ejercían los guardas mediante arrendamiento. De esa manera, cobraban una parte o la totalidad, según los casos, de las multas que se recaudaban por contravenir la ley de los ruedos ${ }^{88}$.

Esas penas eran muy variadas: a los dueños o pastores de las manadas de ovejas y cabras se les imponía una pena de doscientos maravedís o la de un maravedí por cabeza para rebaños de menos de sesenta animales. A los propietarios o ganaderos de reses vacunas y de yeguas diez maravedís por cada una de esas bestias que fuere tomada dentro de los ruedos. No obstan-

*s Ibidem, fols. 30 v. -31 r.2

86 Ibidem, fol. $33 \mathrm{r}$.

87 Ibidem, fol. 33 r. -33 v.

8* ADM, Priego, 14-16, fols. 34 r. -35 r. 
te, las denuncias podían efectuarlas cualquiera de los oficiales públicos del concejo que vieran casualmente el hecho. En estos casos, esos funcionarios recibían un tercio de la pena y el resto se entregaba al guarda del ruedo, el cual no estaba obligado a denunciar las peras de lo que entraba en su arrendamiento al concejo ni a cualquier otra persona, sino únicamente al dueño de la propiedad y con un testigo antes de que pasasen tres días del suceso ${ }^{x "}$.

Las ordenanzas protegían igualmente a las heredades de las villas y lugares del señorio de la invasión del ganado con multas de diversa índole, según la condición del animal y el tipo de cultivo: treinta maravedís por el buey y vaca que fuere tomado en cualquiter época del año dentro de viñas olivares y huertas; igual cantidad por cada bestia caballar que hollara viñedo o huerta; doce, en cambio, si se encontraba en el olivar; por el asno su dueño debía pagar en todos los cultivos cinco maravedís, lo mismo que debía de abonar el propietario del puerco. A las manadas de ovejas y cabras se les sancionaba con la cantidad ya conocida de doscientos maravedís. Estas cuantías se reducían a la tercera parte cuando el estropicio era hecho en zumacares. Por lo demás, a los dueños de las huertas se les concedía la posibilidad de elegir la pena por el peaje o por la tasación de los daños causados por alguna de esas bestias. Ello era debido, sin duda, a que los productos en ellas cultivados eran mucho más delicados y costosos. Tampoco sorprende que se otorgue igualmente esa posibilidad a los campesinos que recibieran el mal de las ovejas y cabras, animales muy dañinos por su insaciable voracidad".

Por otro lado, en las tierras del señorío de Aguilar había una ley que permitía al campesino matar al cerdo que encontrase en su viña después de que a ésta le salieran los pámpanos o en su olivar cuando la aceituna estuviese gruesa. Sólo se le imponían dos condiciones: dejar un rastro de la sangre del animal en el lugar donde le dio muerte y llevarlo o enviarlo a la plaza pública del pueblo para que allí lo reconociera su dueño. No tenía, pues, otra limitación y podía, por consiguiente, dar muerte a todos los cerdos que encontrara en su dominio. Sin embargo, el texto de la nueva ordenanza recoge, quizás para evitar mayores perjuicios, una aclaración importante, la de que el dueño de la heredad sólo matase un animal después de que le hubiera sorprendido por tres veces en la misma temporada bien sólo o en compañía de otros de su misma especie ${ }^{y 1}$.

89 Idem.

(*) ADM, Priego, 14-16, fols. 35 r. -35 v.

91 "Hordenança es antigua en las dichas villas siendo los puercos tomados en las viñas después que salen los pámpanos y en los oliuares después que ay azeytuna gruesa el dueño dela heredad los pueda matar con tanto que quede señal dela sangre en la heredad y los trayga o enbie a la plaça para que su dueño les conosca e si no le pagaren la pena los tome para sy y porque la dicha hordenança es buena para la conseruaçión delas heredades, hordenamos y 
Para proteger todavía más a los cultivos del ganado, los señores de Aguilar ordenaron que todas las huertas y viñas que estuviesen próximas a los campos y a las dehesas fuesen debidamente cercadas por sus dueños de manera que alcanzaran como mínimo cuatro palmos de altura si querían cobrar las penas".2. Quienes no podían beneficiarse de ellas eran los que en adelante dejasen sin labrar ni podar las viñas cinco o más años".

Todas estas medidas iban encaminadas a guardar la integridad de los cultivos frente al ganado. Pero no sólo los animales podían causar destrozos en los ruedos. Y en este sentido, en el libro de ordenanzas de 1519 se adoptan una serie de disposiciones contra las personas que se meten en heredades ajenas, roban uvas, aceitunas u otros frutos, se adentran con ganado en los viñedos o cometen cualquier otro estropicio. Veámoslo con más detenimiento.

En el caso de que se atravesara una viña ajena para ir a otra parte haciendo camino vedado, la multa ascendía por cada vez que esto ocurriera a doce maravedís por persona y a seis por cada bestia; si el labrador con sus bueyes se internaba en el olivar antes de se ser labrado no incurría en pena alguna. Sin embargo, después de arado tenía que marchar por sendas conocidas y dispuestas por el concejo. De lo contrario, la pena era de doce maravedís. Se autorizaba la recogida de espárragos en los olivares pero sin cuchillos, la caza con ballesta y el paseo a caballo, a mula o a pie siempre que se hiciera para desplazarse a la heredad propia. En cambio, estaba penalizado con cuantía de treinta maravedís poner trampas o "perchas" en olivares y viñedos.4.

Los padres de los niños menores de diez años sorprendidos robando en viña, huerta u olivar o segando alcacer ajeno pagaban multa de doce maravedís. Los de once, doce y trece años cincuenta o cien, dependiendo de si el daño lo hacían de día o de noche, y, los mayores de catorce años, quinientos. Esto por la primera vez. La reincidencia en el delito se castigaba con la pena doblada. La tercera ocasión resultaba físicamente más dolorosa: el infractor recibía públicamente o en la cárcel, esto dependía de la condición de la persona, cincuenta azotes"s.

mandamos que se guarden y executen con esta moderaçión e aclaraçión. Que esto se entienda y guarde aviendo tomado aquellos puercos tres vezes en aquella temporada en la tal heredad y que no pueda matar más de uno o dos puercos y que sea creydo por su juramento para todo lo que dicho es el dueño del dicho oliuar o viña mostrando todavía la sangre en la heredad” (ADM, Priego, 14-16, fols. 35 v.-36 r.).

"2 ADM, Priego, 14-16, fol. 36 r.

"Idem.

9.t ADM, Priego, 14-16, fol. 36 v.

" «Otrosi, hordenamos y mandamos que qualquyera que desfrutare viña o huerta o oliuar o segare alcaçer ajeno si fuere niño de hasta dies años que pague doze marauedís de 
Unas normas, en cambio, penalizan los desplazamientos con ganado por los caminos existentes entre las viñas y los olivares, por ejemplo, a quienes conducían de esta manera sus animales a las dehesas de Panchía y Panchuela. En este caso, el importe de las penas que debían de pagar los infractores era de diez maravedís por la res vacuna, cinco por la yegua y uno por cada cerdo, oveja o cabra". Otras leyes dejan únicamente para los asnos, caballos y animales de labranza el pasto de las hazas del alcacer después de haber sido segadas". Por último, los establecimientos prohiben el rebusco en las viñas porque las personas que lo hacían aprovechaban la ocasión para robar las aceitunas del olivar que allí se cultivaba ${ }^{17}$.

Tres leyes nos hablan de los ruedos de las colmenas. La primera los defiende del ganado de ovejas y cabras en tiempo de uvas con la pena pecuniaria ya conocida. Pero también prohibe la existencia de colmenas en las viñas desde el día de Santiago (25 de julio) hasta el quince de octubre, en este caso con multas de cinco o de diez maravedís por cada colmena, según fuese el dueño

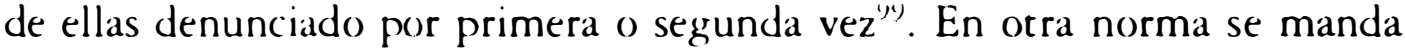

pena por cada vez e si fuere mayor desta hedad e desfrutare o segare de día que pague a la guarda que lo tomare o al dueño dela heredad çinquenta marauedís e si fuere de noche çien marauedís siendo de quatorze años arriba que pague quinyentos marauedís la mytad para nuestra cámara e la otra mytad para las obras públicas dela tal villa o lugar y por la segunda vez que fuere tomado pague la pena doblada y por la terçera vez le den çinquenta açotes públicamente por la villa o en la cárçel, segúnd la calidad dela persona e pague en qualquyera delos dichos casos la fruta o daño al dueño y en lo que toca a las penas pecuniarias que sea creydo la guarda o of içial público o dueño dela heredad o hijo o moço o criado del tal dueño por su juramento y que tomándolo hijo o moço del dueño dela heredad pueda llevar la pena el tal dueño y quanto a las penas susodichas se guarde el horden contenydo en la dicha ley segunda título terçero delos estableçimientos desta segunda parte y quanto a la pena delos açotes en el proçeso e probança se guarde la disposiçión del derecho" (ADM, Priego, 14-16, fol. 37 r.).

\% ADM, Priego, $14-16$, fols. 37 v. -38 r.

" "Por quitar la ocaçión delos daños y penas e questiones y enojos que por cabsa de querer cada uno comer su aza de alcaçer después de segada se pueden recresçer se hordena y manda que después de segados los alcaçeres no se puedan comer las dichas haças del ruedo con ningúnd ganado vacuno ny ovejuno ny con cabras ny yeguas, eçebto con asnos e caballos y que los bueyes que vinieren a arar los oliuares e viñas y heredades del ruedo o linde a él puedan gozar delas dichas haças segadas durante los días dela labor según que en lo que toca al ganado que puede pastar el ruedo por otras ordenanças está declarado solas penas delos senbrados del ruedo que es diez marauedís de cada cabeça de res vacuna o yegua y de manada delos otros ganados dozientos marauedís y de manada abaxo de cada cabeça un marauedís y en el proçeso y execuçión se guarde la dicha ley segunda título terçero delos estableçimientos desta segunda parte» (ADM, Priego, 14-16, fol. 38 r.).

" ADM, Priego, 14-16, fol. 38 r.

" "Hordenamos y mandamos que en los ruedos delas colmenas delas dichas villas $e$ lugares no entren ningunos ganados de ovejas e cabras en tanto que hay uvas ny estén col- 
que las cabras duerman durante esa época fuera del ruedo de las viñas y que los perros de los ganados lleven obligatoriamente cencerros con badajo y todos los de la villa garabatos de cinco palmos de largo en el cuello. Estos animales podían ser apaleados si se les cogía merodeando en las viñas a lo largo de ese período y matados si además no portaban cencerro ni garabato ${ }^{100}$.

La tercera ley se refiere al amojonamiento del ruedo de Montilla y al que había entre esta población y la de Aguilar, el cual se hace, como era habitual, teniendo en cuenta la geografía del terreno. Se citan además de lomas, cerros, peñas y sierras, ríos, arroyos, fuentes, pozos y lagunas. También se mencionan en el deslinde caminos, veredas, cortijos y casillas. Algunos de los tóponimos se han conservado en la actualidad. Los límites del ruedo de Montilla parecen coincidir con los de su término actual, al igual que la divisoria que se establece entre esa localidad y la de Aguilar a partir de la loma de La Peña del Angel hacia el este a través del Sotollón hasta llegar a Ríofrío y hacia el oeste siguiendo el curso del arroyo hasta alcanzar a las veredas de Panchía y después el Molino Nuevo ${ }^{101}$.

\section{e) Normas sobre las penas}

El capítulo undécimo del cuaderno de ordenanzas contempla también en su articulado tres normas, que tienen en común el tema de las penas. En primer lugar, se habla de las personas con facultad para imponer multas y prender conforme a las leyes, que son los guardas, mayordomos del campo y cualquier otro oficial público del concejo (regidor, jurado, alcalde, alguacil, mayordomo y escribano). Y pueden hacerlo contra el señor del ganado o contra el pastor o ganadero, según estimen más conveniente. Ahora bien, sólo estaban autorizados a ejercer ese derecho si eran testigos del daño. No obstante, esa condición dejaba de tener efecto en el tema de las talas y cortas del arbolado y en el robo de cepas en las dehesas. También podían imponer sanciones los aparceros de los

menas dentro desde el día de Santiago del mes de jullio hasta quinze días entrados de otubre so pena de dosientos marauedís por cada manada e si no fuere manada de cada cabeça un marauedís y por cada colmena çinco marauedís por la primera vez e diez marauedís por la segunda y que a costa del dueño se hechen fuera e por cada vez adelante se yncurra en la dicha pena de diez marauedís, la mytad delas dichas penas para el conçejo e la otra mytad para la guarda o ofiçial público que lo tomare y que en la execuçión dello se guarde lo que se dispone en la dicha ley segunda título terçero" (ADM, Priego, 14-16, fol. 39 r.).

${ }^{1(16)}$ ADM, Priego, 14-16, fols. 39 r. -39 v.

101 Ibidem, fols. 39 v. -40 r. 
cortijos en los sembrados y rastrojos. iEn qué tiempo se debían pedir las penas:"in?

La ley segunda establece que las referentes a los ganados de los vecinos de las villas y lugares del señorio debian demandarse en los nueve días siguientes a la realización del daño y ser ejecutadas en el plazo de dos meses. Quedaban prescritas cuando el dueño de la tierra cultivada desconociera los hechos a lo largo de seis meses. En los sembrados y campos de cereal la pena podía demandarse durante todo el año hasta el quince de agosto con tal de que fucse ejecutada en septiembre; en los rastrojos dentro de tres meses. Los guardas del ruedo que debían denunciar los hechos durante los nueve primeros días tenían que tener también rematada la prenda de los vecinos a los veinte días de haberlos denunciado, pero ese plazo se alargaba a dos años para los delitos cometidos por los forasteros, cuyo rastro e identidad era más difícil de encontrar. La pena por la tala de árboles y el hurto de cepas en dehesas o de bellotas debía de pedirse igualmente en los nueve días antedichos y ser ejecutada hasta el mes de la denuncia, siempre que el guarda u oficial público hubiese encontrado al infractor haciendo el daño. En caso contrario, es decir cuando no eran testigos directos de los hechos, sino que tenían que probarlos mediante pesquisa -cosa que no era necesaria en el robo de bellotas-, esa demanda la hacían en el plazo de un mes y se ejecutaba dentro de cuarenta días ${ }^{113}$.

Por último, los guardas, oficiales públicos y personas autorizadas a denunciar las infracciones debían comunicarlas al alcalde y al escribano del concejo dentro de los tres días siguientes a la realización del daño, siempre que éste se hubiese producido en cualquier cultivo, dehesa o monte defendido por el concejo. Ese escribano, u otro notario del municipio, anotaba esas acusaciones en un libro y luego las presentaba en el cabildo de cada semana. Por encima de esos guardas y oficiales, los señores de Aguilar pusieron en las villas y lugares del señorío un ejecutor para demandar las correspondientes penas a los miembros del concejo o a cualquier transgresor de las leyes contenidas en este libro de ordenanzas ante las justicias del lugar, el alcalde mayor del señorío o incluso ante ellos mismos. Igualmente podía hacer denuncias en cualquier parte del estado. Al mismo tiempo, se ordena a todos los jueces que recauden las penas de los infractores a la mayor brevedad ${ }^{104}$.

El cumplimiento de las normas relativas a la fijación de penas era de gran valor porque el dinero así obtenido suponía una fuente importante

102 Ibidem, fols. $40 \mathrm{r} .-41 \mathrm{r}$.

104 ADM, Priego, 14-16, fols. 41 r. -41 v.

${ }^{10}$ Ibidem, fols. 41 v. -42 r. 
de ingresos para el municipio, dado que buena parte de las transgresiones se hacían contra la propiedad concejil. Por ese motivo había la obligación de hacer constar formalmente por escrito las denuncias en un libro del concejo. De ahí también que se castigue con gran rigor a los funcionarios acusados de malversación y oclusión de fondos. Una parte del importe de las multas las destinaba el concejo a realizar obras públicas. Pero, generalmente, la cuantía de la multa era compartida. En ocasiones se repartía a medias o al tercio, dependiendo del número de beneficiarios. Estos, además del organismo municipal podían ser los oficiales públicos que realizaban la denuncia -guardas, mayordomos de campo, diputados del mes, alguacil mayor, escribano del concejo, etc.-, cualquier vecino mayor de edad que hiciera lo pertinente o sufriera el daño y los propios titulares del señorío.

Una vez hecho, el libro de ordenanzas tenía obviamente que ser aprobado por los señores de la casa de Aguilar. A continuación, se procedía a darle la máxima publicidad en las villas y lugares del señorío, donde, por otra parte, había de quedar una copia del mismo, debidamente autentificada con la firma del escribano del concejo de Aguilar o la del de Montilla, en un lugar visible para que fuese consultado cada vez que hubiese necesidad de ello. Por lo demás, aquella divulgación se llevó a efecto mediante pregones, cosa lógica teniendo en cuenta que la mayoría de los interesados no sabía leer y que ésta sería además la mejor forma para que tales ordenanzas las pudieran escuchar un alto número de personas. El pregón se realizó en presencia del escribano de la villa o lugar en la plaza pública, el lugar más populoso y frecuentado por los vecinos.

Pero mejor será recoger el contenido del texto en toda su extensión e integridad para comprender mejor lo anteriormente expuesto: "Otrosy, porque las dichas hordenanças y estableçimientos mejor vengan a notiçia de todos, mandamos que se lean e publiquen en cada una delas dichas villas e lugares del principio hasta el fin en tres o quatro días de fiesta en la plaça pública por manera que venga a notiçia de todos o dello no puedan pretender ynorançia, y que en cada una delas dichas villas e lugares aya una copilaçión e libro destas dichas hordenanças firmado e signado del escriuano de conçejo dela villa de Aguilar o del escriuano de conçejo dela villa de Montilla, el qual dicho libro esté enquadernado y se ponga en parte donde todos puedan recurrir a él quando el caso o la duda se ofreçiere; e mandamos que el dicho libro de hordenança faga fee en juysio e fuera dél e prueve en todas las cabsas y en ellas conforme a las dichas hordenanças se jusgue e cada una dellas por sí tratada haga fee sobre el caso que se resentare y estas hordenanças originales mandamos estar en la parte o lugar que más convenga e por la presente mandamos a todos los conçejos, alcaydes, alcaldes, regidores, alguasiles e jurados e 
ofiçiales de conçejo, cavalleros, escuderos e hombres buenos destas dichas villas e lugares que guarden e cumplan e fagan guardar e cumplir las dichas hordenanças en todo y por todo y por la forma que en ellas se contiene, no yendo cosa alguna contra el tenor dellas solas penas contenydas en las dichas hordenanças. Dadas en la villa de Aguilar a veinte días del mes de disiembre año del nasçimiento de nuestro Saluador Ihesu Xpto de mill e quinientos e diez e nueve años" "11's.

\section{RÉSUMÉ}

Cette étude est principalement basée sur les ordonnancés que promulguèrent les marquis de Priego en 1519. A mon avis ce document possède une grande importance. Et ceci pour plusieurs raisons. Tour d'abord pour la quantité de données qu'il offre sur l'organisation institutionnelle et économique de l'état d'Aguilar, à l'aube de l'époque Moderne. Deuxièmement parce qu'il s'agit du premier document seigneurial de cet acabit qui semble avoir pu être conservé dans la province actuelle de Cordoba. Troisièmement, parce que l'ensemble des articles se rapportent à une partie importante du territoire de cette même province, car elle comprend les villages et lieux tels que Aguilar, Montilla, Puente Genil, Montalban et Monturque. Quatrièmement, car, jusqu'à ce jour, il n'avait pratiquement pas été publié.

Ces ordonnances qui ont été recueillies dans un cahier de quarante deux folios, offrent, comme c'est la coutume, plusieurs parties. Un prologue dans lequel les seigneurs exposent les motifs de la promulgation; les titres ou chapitres des ordonnances, qui apparaissent inclus dans deux parties différentes: la première comprend dix chapitres dans lesquels on fait allusion aux faits de la vie municipale et aux questions relatives aux boucheries, au vin, au commerce et aux parades militaires; dans la seconde, par contre, les lois touchent fondamentalement à la défense des recours naturels des limites des bourgades ci-dessus mentionnées, faisant plus spécialement allusion aux rivières, montagnes et bois, domaines, pâturages et troupeaux, champs ensemencés et chaumes, foyers, arènes, ruchers ainsi que les amendes et infractions contre la législation. La signature des seigneurs de Aguilar. La date de promulgation des ordonnances et la preuve qu'elles avaient été publiés.

\section{SUMMARY}

This study is based, mostly, on the ordinances that the Marquis of Priego promulgated in 1519. The document is, in my opinion, quite important.

105 ADM, Priego, 14-16, fols. 42 v. -43 r. 
Several reasons lead us to this conclusion. First of all the amount of preces of information that it provides about the institutional and economic organisation of Aguilar's State at the beginning of the Modern Age. Secondly, because it is the first aristocratic document of this kind that, apparently, has been kept in the Province of Córdoba. Thirdly, because its articles refer to an important part of its territory, since it includes the villages and townships of Aguilar, Montilla, Puente Genil, Montalbán y Monturque. And forthly, because till now it has remained almost unpublished.

These decrees, that were collected together in a notebook of forty-two pages, are divided, as it is usual, in different parts. 1. A prologue, where the landlords expose the motives of the promulgation; 2. The titles or chapters of decrees, that appear integrated in two different parts: the first one has ten chapters and reference is made in them to municipal life and aspects related to butcher's shops, wine, trade and militar parade; the second one, on the contrary, laws are related to the defense of natural resources in the townships of the above mentioned villages, with special reference to rivers, mountains, woodland, country estates, pastures and livestock, sown fields and stubbles, fires, arenas, apiary and to the respective fines or infractions against what had been legislated; 3 . The signature of the Landlords of Aguilar; 4. The date of promulgation and 5 . The testification that they had been proclaimed. 